\title{
Current review of genetics of human obesity: from molecular mechanisms to an evolutionary perspective
}

David Albuquerque ${ }^{1}$, Eric Stice ${ }^{2}$, Raquel Rodríguez-López ${ }^{3}$, Licíno Manco ${ }^{1}$, Clévio Nóbrega $^{4}$

${ }^{1}$ Research Centre for Anthropology and Health (CIAS), Department of Life Sciences,

University of Coimbra, Portugal

${ }^{2}$ Oregon Research Institute, Eugene OR, USA

${ }^{3}$ Servicio de Análisis Clínicos, Consorcio Hospital General de Valencia, Valencia, Spain

${ }^{4}$ Center for Neurosciences \& Cell Biology, University of Coimbra, Portugal

Keywords: Obesity, genetics of obesity, epigenetics, microRNAs, evolutionary perspectives, nutrigenomics.

Running head: The genetics of human obesity

Corresponding author:

David Albuquerque

Research Centre for Anthropology and Health (CIAS)

Department of Life Sciences, University of Coimbra

3000 Coimbra (Portugal)

Phone: +351-239-829051; Fax: +351-239-823491

E-mail: dav.albuquerque@gmail.com

\section{Abstract}

Although the prevalence of obesity is increasing in most countries, partially due to 
ubiquitous exposure to energy dense foods, not everyone exposed to the current obesogenic environment shows unhealthy weight gain. This suggests that there are marked differences in genetic factors that increase vulnerability for excess weight gain. Indeed, evidence suggests that 40 to $70 \%$ of variance in unhealthy weight gain can be attributed to individual genetic variations. Moreover, emerging data imply that genetic vulnerability factors interact with environment risk, which is referred to as an epigenetic process. Whereas most scholars consider obesity to be a disorder that results from the interaction between lifestyle and genetic factors, its origin is complex, poorly understood, and extent treatments are typically ineffective. Like any other aspect of science, our knowledge about the genetic basis of obesity is under constant revision. The current paper provides a review on the origins, mechanisms, evolutionary explanation, prevention and treatment based on genotyping.

\section{Introduction}

For a considerable period of prehistory, hominins were primarily hunter-gatherers. In that period food was severely limited, which resulted in natural selection for humans who 
had the capability of storing energy as fat. Today, food is easily available in modern societies, resulting in different natural selection processes. On the other hand, the changes in our environment occurred more rapidly than the modifications in our genetic background. In fact, our genetic background is not very different from 12,000 years ago, which correspond to the beginning of the agriculture development (Bellisari 2008). This means that there might be a delay in the adjustment of the genetic profile to environment, and that our genetic background is similar to the one from the time our forefathers were foragers. Therefore, when considering the imbalance in our modern lifestyle and our "ancient" genetic profile, it is understandable that many people gain weight so easily. When human morphology is considered, there are profound individual differences, such as body size, hair color/form, eyes color/form, etc. These human variations were due, in part, to evolutionary forces, environmental conditions, among others. However, in all societies and subpopulations, there are both obese and non-obese individuals. The difference arises primarily as a consequence of genetic factors, as is revealed by the high heritability for body mass index (BMI) (Feinleib et al. 1977; Stunkard et al. 1986a; 1986b; Silventonien et al. 2010). A trait can reflect the activity of a single-gene (Mendelian or monogenic) or more than one gene (polygenic); both cases, being influenced by environmental factors. The polygenic multi-factorial condition reflects the additive contribution of many genes conferring different degrees of susceptibility. Accordingly, we may understand a polygenic trait as the combined action of several genes producing a "continuously varying" phenotype. With the advent of the Human Genome Project (1990-2003), millions of DNA sequence variants were discovered in the human genome. This large and diverse database of polymorphism markers provided a novel opportunity to study the human genetic basis of several complex diseases through population approaches. In the study design of population approaches, a significant amount of individuals must be screened for a large number of polymorphisms. If a mutation increases susceptibility to a specific disease of interest, we 
should note that it is more common among individuals affected by this condition than among non-affected individuals. Thus, through the genotyping of significant number of individuals, the population genetics tools are able to highlight the genetic basis of polygenic diseases, such as obesity.

\section{Obesity}

Human obesity is a global public health concern and results from an excessive accumulation of body fat that can adversely affect health (Haslam and James 2005). The global rise of obesity has serious effects, may contribute for a significant number of diseases including type 2 diabetes mellitus, cardiovascular diseases, metabolic syndrome, and some cancers (Haslam and James 2005; Swinburn et al. 2011). Beyond co-morbidities, obesity has an immense social impact and substantial direct, and indirect, cost in healthcare services (Swinburn et al. 2011). Excessive fat accumulation results from a persistent positive energy balance, that is, the amount of energy consumed exceeds the amount of energy expended (Silventonien et al. 2010). So, a simple definition of obesity could be a consequence of an imbalance between energy intake and energy expenditure (Sandholt et al. 2012). The energy balance represents a conglomerate of traits, each one influenced by numerous variables such as behavior, diet, environment, social structures, metabolic factors and genetics (Mathes et al. 2011). The result of this complex interaction among all of these variables contributes to individual differences in the development of obesity.

Epidemiological studies indicate that adiposity, as reflected by BMI, has increased worldwide over the past decades (Finucane et al. 2011). Moreover, obesity is more common in some countries than in others, though precise cross-country comparisons can be difficult because not all samples are representative of the relevant populations. Nonetheless, available data suggest that the increase in the prevalence of obesity began to emerge during the 1980s and ever since more countries have joined the global obesity pandemic (Finucane 
et al. 2011). Between 1980 and 2008, the global change per decade for age-standardized mean BMI was increased $\sim 0.4 \mathrm{~kg} / \mathrm{m}^{2}$ and $\sim 0.5 \mathrm{~kg} / \mathrm{m}^{2}$ in men and women, respectively (Finucane et al. 2011). By 2008, the estimated prevalence of obesity in men and women was $9.8 \%$ and $13.8 \%$ respectively, comparing with $4.8 \%$ in men and $7.9 \%$ in women in 1980 . Worldwide estimation in 2008 for the prevalence of overweight $\left(\mathrm{BMI}>25 \mathrm{~kg} / \mathrm{m}^{2}\right)$ and obesity $\left(\mathrm{BMI}>30 \mathrm{~kg} / \mathrm{m}^{2}\right)$ among adults (>20 years) was, 1.46 billion (34.3\%); and from those 502 million (11.8\%) were obese (Finucane et al. 2011). In modern societies, despite obesity awareness campaigns and efforts to decrease in energy intake and increase in energy expenditure, obesity prevalence is increasing. However, we don't yet understand why not everyone in our societies becomes obese. Obesity has a multi-factorial etiology, involving various non-genetic and genetic factors (Haslam and James 2005; Xia and Grant 2013). Probably most cases of obesity results of a cluster towards the middle of this spectrum, which can be best described as the outcome of an adverse obesogenic environment, working on a susceptibility genotype. Effectively, the genetic susceptibility can potentially be mediated through defects in several different homeostatic mechanisms. Certainly, the exposure to an obesogenic environment could be the cause of the increase in the prevalence of high BMI for the last 30 years (Haslam and James 2005; Finucane et al. 2011; Swinburn et al. 2011). The field of genetic epidemiology aims to use systematic methods to investigate the influence of human genetic variation on health and disease, and also the relationship between environmental factors and disease.

\section{Genetic obesity}

The increase in the obesity prevalence around the world has been broadly attributed to the change in environment, which is more obesogenic, against an evolutionary background, which could be maladaptive in this new obesogenic context. On the other hand, specific features of the energy balance mechanisms can effectively protect against obesity, possibly 
explaining why one third or more of the population remains lean ( $O^{\prime}$ Rahilly and Farooqi 2008). The obesity phenotype only emerges if food consumption exceeds than energy expenditure on a lasting basis, resulting in a prolonged positive energy balance. However, there are many risk factors that predict the development of obesity and generally all involve the interaction of biological and social factors. Numerous studies are consistent with the thesis that the personal genetic profile could be a cause for individual differences in the predisposition to weight gain. It is, therefore, interesting that most of the genes involved in the susceptibility of obesity are also related to food intake and regulation of energy balance (O'Rahilly and Farooqi 2008). Based on genetic and phenotypic characteristics, three types of obesity forms can be considered: monogenic syndromic obesity, monogenic nonsyndromic obesity and polygenic (common) obesity.

\subsection{Evidence for a genetic component to obesity}

Over the last 30 years, the increase in the prevalence of obesity could be attributed to environmental changes, or to high-calorie food intake together with the sedentary lifestyle of modern societies (Xia and Grant 2013). These data appear to be inconsistent with twin and adoption studies that have concluded that approximately $80 \%$ of the variance in obesity is due to genetics (Feinleib et al. 1977; Stunkard et al. 1986a; 1986b; Silventoinen et al. 2010). The fact that the prevalence of obesity in many countries has increased 3 -fold over the last 3 decades seems incompatible with the notion that genetics are the primary cause of obesity because genetic adaptation theoretically take much longer, requiring several generations at a minimum. Thus, other factors, like methylation (or other epigenetics mechanisms), in which environmental factors cause changes in the expression of genes, could explain the increase in obesity prevalence.

Heritability represents the proportion of phenotypic variation among individuals due to genetic contribution. Hence, it is not surprising that one important risk factor for childhood 
and adolescent obesity is parental obesity. Whitaker et al. (1997) found that when both parents are obese there is an increase of more than double of the risk for childhood obesity. However, most of the studies found a small to medium effect of parental obesity as risk factor for childhood obesity (Danielzik et al. 2002). Other studies have found a stronger effect for maternal obesity compared to paternal obesity, which may reflect pre- and postnatal environmental factors (Magnusson et al. 2002). Moreover, maternal weight gain in pregnancy has been positively associated with BMI of the children into adulthood (Mamun et al. 2009).

Twin studies have been used to model the genetic component of a given trait, due to the fact that monozygotic (MZ) twins are genetically identical, while non-identical dizygotic (DZ) twins share only 50\% of their genetic material (Xia and Grant 2013). In 1977, Feinleib et al. studied the correlations for weight in $250 \mathrm{MZ}$ and $264 \mathrm{DZ}$ male veteran twin pairs, and established for the first time that familial aggregation for obesity results mainly from genetic influence. In 1986, Stunkard et al. (1986a) confirmed these results in a 25 -year follow-up study using more than $4000 \mathrm{MZ}$ and DZ twin pairs. High heritability values for BMI were observed for the same subjects at 20 years $\left(h^{2}=0.77\right)$ and at 45 years $\left(h^{2}=0.84\right)$. The heritability of fat mass among $M Z$ twins has been reported to range from $70-90 \%$, while in DZ twins it is $35-45 \%$. Adoption studies have strengthened the evidence of a strong genetic influence on human body weight. Body corpulence of adopted children correlates more strongly with $\mathrm{BMI}$ of their biologic parents versus the $\mathrm{BMI}$ of their adoptive parents (Stunkard et al. 1986b). Recently, Silventoinen et al. (2010), conduct a review of studies in twins and adopted children, suggesting that genetic factors could have a much stronger effect than environmental factors on the BMI trends in children up to the age of 18 years.

Another genetic component for obesity is highlighted through the different prevalence between racial groups. For example, it was found that obesity prevalence in Caucasian and Asian populations is of about $35 \%$ or less compared to $50 \%$ or more found among Pima 
Indians living in New Mexico (Knowler et al. 1990). Several studies support the concept that genes play a key role in the obesity etiology. However, the search for underlying genotypes that cause of obesity has been challenging due to the complex interactions involved in the regulation of adiposity. Indeed, the vast majority of individual genotypes that have been associated with elevated body mass have not replicated in a reliable fashion. Moreover, environmental factors and cultural diversity also account for the different obesity prevalence found across ethnicities.

\subsection{Mendelian forms of obesity}

Monogenic forms of obesity result from an alteration of a single gene and are rare, affecting about 5\% of the population and severe (Farooqi and O'Rahilly 2005; GonzálezJiménez et al. 2012). There are more than 200 cases of human obesity associated with homozygous forms of a single gene mutation (Bell et al. 2005; Rankinen et al. 2006). Two forms of Mendelian inheritance of obesity could be found: syndromic and non-syndromic. Most of these monogenic forms of obesity are characterized by an early-onset of the disease and an extreme phenotype (Faroogi and O'Rahilly 2005). In the search for homologous mutations in mice, several human forms of obesity have been identified (Huszar et al. 1997). Thus, murine models appear useful to understand the molecular pathogenesis of human obesity (Lutz and Woods 2012). Family studies based on individuals with extreme obesity, also proved to be very successful in the detection of obesity-related mutations (Hinney et al. 2010).

\subsubsection{Non-syndromic form of obesity}

Over the past 15-20 years, several gene mutations have been shown to cause autosomal recessive forms of obesity. More than 200 single-gene mutations have been found to cause human obesity (Mutch and Clément 2006). Interestingly, all these mutations 
can be found in only ten genes (Rankinen et al. 2006). However, these mutations are rare and lead to extreme obesity with an early-onset obesity and other endocrine disorders (González-Jiménez et al. 2012). There are eight well-known genes mutations in monogenic non-syndromic form of obesity explaining up to $10 \%$ of cases with early-onset extreme obesity, affecting $L E P, L E P R, P O M C, P C S K 1, M C 4 R, B D N F, N T R K 2$ and SIM1 (Table 1) (Farooqi and O'Rahilly 2005; Ranadive and Vaisse 2008; González-Jiménez et al. 2012). All these genes code for proteins with a central role in the leptin-melanocortin signaling pathway present in the hypothalamus, and therefore affect regulation of food intake and energy expenditure (González-Jiménez et al. 2012). This pathway is activated when LEP is secreted by the adipose tissue, binds to its receptor, localized in the surface neurons in the arcuate nucleus of the hypothalamus (Dubern and Clément 2012). The signal that regulates satiety and energy homeostasis is then propagated through the $P O M C /$ cocain and amphetamine related transcript (CART) and melanocortin system (González-Jiménez et al. 2012). While POMC/CART neurons synthesize anorexigenic peptide alpha-melanocyte-stimulating hormone ( $\alpha-M S H)$, a distinct group of neurons synthesizes the orexigenic peptide neuropeptide $Y(N P Y)$ and agouti related protein (AGRP), which act as inhibitors of MC3 and MC4 receptors (Harrold and Williams 2006). The derived peptide nature of POMC depends of the endoproteolytic type enzyme present, specific in brain region. In the anterior pituitary, the PCSK1 enzyme produces adrenocorticotropic hormone (ACTH) and $\beta$-lipotropin ( $\beta$-LPH), while the combined presence of PCSK1 and PCSK2 in the hypothalamus control the production of $\alpha-, \beta-, \gamma-$ MSH and $\beta$-endorphins (González-Jiménez et al. 2012).

The protein encoded by the $M C 4 R$ gene, is a membrane-bound receptor and a member of the melanocortin receptor family (Hinney et al. 2013). The protein interacts with adrenocorticotropic and MSH hormones and is mediated by G proteins. The MC4R gene is composed by a single exon, and is located in the chromosome 18q21.3, encoding for the 332-amino acid seven-transmembrane G-protein-linked receptor, critically involved in 
regulating energy balance (Grantz et al. 1993). It is expressed mainly in the central nervous system, including in the hypothalamus, contributing to food intake and energy expenditure regulation (Grantz et al. 1993; Mountjoy et al. 1994). In 1998, two independent groups reported a mutation in the $M C 4 R$ gene, which result in a non-functional receptor causing severe early-onset obesity (Vaisse et al. 1998; Yeo et al. 1998). In morbidly obese individuals, deficiency in the MC4R gene activity represents the most common cause (1 to $6 \%$ ) for the obese phenotype (Yeo et al. 1998; Farooqi et al. 2003; Beckers et al. 2006). More than 150 variants of this gene have been described, usually classified into five classes depending of their molecular effects (Hinney et al. 2013).

The LEP gene (chromosome 7q31.2) encodes a protein that is secreted by white adipocytes, which plays a central role in body weight regulation (Dubern and Clément 2012). This protein, acts as part of a signaling pathway that can inhibit food intake and/or regulate energy expenditure to maintain constancy of adipose mass. In 1997, in a screening for serum level concentrations in severely obese subjects, two children of the same family were found with undetectable levels of leptin (Montague et al. 1997). Research subsequently revealed that leptin deficiency is inherited and produces extreme early onset obesity (Rau et al. 1999). This deficiency can be caused by a frameshift mutation (del G133), which produces a truncated protein that is not secreted (Rau et al. 1999) or a missense mutation Arg105Trp, which is associated with low levels of circulating leptin (Strobel et al. 1998).

The protein encoded by the LEPR gene (chromosome 1p31.3) belongs to the gp130 family of cytokine receptors, which stimulate gene transcription via activation of cytosolic STAT proteins, predominantly in the hypothalamic neurons (Bates and Myers 2003). This protein is a receptor for leptin and is involved in regulation of fat metabolism. A splice site mutation in the exon 16 is associated with leptin receptor deficiency, producing extreme obesity (Clément and Ferré 2003). 


\subsubsection{Syndromic form of obesity}

Syndromic forms refer to obesity cases that occur in a distinct set of associated clinical phenotypes, such as mental retardation or organ-specific developmental abnormalities (Ichihara and Yamada 2008). There are more than 30 Mendelian disorders that result in obesity (Mutch and Clément 2006). Research is beginning to determine the genetic basis of some of these syndromes, thus elucidating the pathogenesis of the chronic positive energy balance. The genetic basis of these disorders is extremely heterogeneous. Table 1 presents the most common forms of early-onset syndromic obesity for which the genetic basis is, at least, partially understood, including WAGR (Wilm's tumor, aniridia, genitourinary anomalies and mental retardation), Prader-Willi, Bardet-Bield, Altröm and Cohen syndromes.

WAGR syndrome is a rare genetic disorder characterized by a deletion at chromosome 11 p13 in a region containing the Wilm's tumor 1 (WT1) and paired box 6 (PAX6) genes (Farooqi and O'Rahilly 2005). A specific type of WAGR has been associated with a deletion in the brain-derived neurotrophic factor (BDNF) gene, which results in an obese phenotype.

Prader-Willi syndrome (PWS) can have several etiologies, characterized by central obesity, neonatal hypotonia, hyperphagia, hypothalamic hypogonadism, and mild mental retardation, with such abnormalities as short stature and peculiar facial features (Farooqi and O'Rahilly 2005). Most of the cases were associated with loss of expression from paternal deletions of the 15q11.2-q12 chromosomal region (González-Jiménez et al. 2012).

Bardet-Biedl syndrome (BBS) is characterized by early-onset obesity, which is associated with progressive cone-rod dystrophy, morphological finger abnormalities, dyslexia, learning disabilities, and progressive renal disease (Farooqi and O'Rahilly 2005). BBS has extensive genetic heterogeneity with at least 14 loci, (often called BBS gene) and several mutations identified within these loci (González-Jiménez et al. 2012).

Finally, Alström (ALMS) and Cohen syndromes are associated with childhood mild truncal obesity and small stature (Farooqi and O’Rahilly 2005; González-Jiménez et al. 2012). 
Both of them are autosomal recessive and genetically homogenous. ALMS is caused by a balanced translocation of chromosome $2 \mathrm{p} 13$ that disrupts ALMS1 gene or by a small number of mutations in this gene. Cohen syndrome results from mutations in the $\mathrm{COH} 1$ gene, located at chromosome $8 q 22$, which encodes a transmembrane protein of unknown function (Farooqi and O’Rahilly 2005).

\subsection{Polygenic or common obesity}

In most modern societies, the environment favors weight gain rather than loss due to food abundance and lack of physical activity. However, the genetic and molecular mechanisms involved in body weight regulation are complex and not completely understood. The genetic profile of polygenic, obesity results from the effects of several altered genes (Rankinen et al. 2006). In theory, the genetic basis of polygenic obesity implies that the specific set of variants relevant for obesity vary considerably from one obese person to the next (Hinney et al. 2010).

\subsubsection{Genetic approach for common obesity}

The study of common obesity is based in the analysis of gene variation in genomic DNA (single nucleotide polymorphism, or repetition of bases of polyCAs or microsatellites) situated within or near candidate genes. In contrast with monogenic obesity, in polygenic obesity each mutation leads to a variant that confers susceptibility, requiring additionally the presence of other variants and an obesogenic environment to determine the obese phenotype (Razquin et al. 2011). There are two main approaches for the detection and analysis of a candidate gene in body weight regulation: linkage analysis and association studies. Linkage analysis (family studies) has been successful in mapping genes responsible for mendelian diseases, and chromosomal regions associated with susceptibility to the development of complex disorders, whereas association studies (case-control studies) 
identified associations between polymorphisms and traits. Both determine whether an association between a genetic variation and obesity-related trait exist. Association studies have identified several genes for several common diseases. Nevertheless, despite the identification of genetic variants, the results obtained from genome-wide associations have not been replicated consistently possibly due to differences in the study design or insufficient power of the sampled population.

\subsubsection{Candidate gene study}

The candidate-genes association study approach was the first method to search for genes that correlate with common obesity (Day and Loos 2011). In obesity studies the focus has been on polymorphisms in a gene within a linkage region (Hinney and Hebebrand 2008) or genes known for coding proteins involved in the regulation of lipid and glucose metabolism, food intake or energy expenditure (Bell et al. 2005; Day and Loos 2011). More than 300 chromosomal loci show some evidence of linkage with obesity (Rankinen et al. 2006; Loos 2012). Nevertheless, few genes ( 20) supported by at least five positive studies have been associated with common obesity using the candidate gene approach (Mutch and Clément 2006). One of the main limitations of this approach is the need to understand the biological pathways of the disease. Generally, most of the complex diseases like obesity are not yet understood, nor the molecular mechanisms underlying its pathogenesis. Interestingly, genetic mutations that produce monogenic forms of obesity do not appear to be involved in the development of common forms of obesity (Mutch and Clément 2006).

\subsubsection{Genome-wide approach}

The first results about human variation provided by the Human Genome Project (initiated in 1990) led to the development of a new strategy in the search for genes associated with complex phenotypes (Sandholt et al. 2012). The Genome-wide linkage scans 
identify loci associated with complex traits (Bell et al. 2005). This strategy involves the typing of families with multiple cases and tests some chromosomal regions capable of harboring one or more genes co-segregating with the trait. It is more useful than the previously approach because it doesn't require previous knowledge of the genes that underlie the trait or phenotype. However, in the case of obesity, these studies did not identify multiple variants, mostly because common variants with high penetrance do not contribute substantially to the risk of common forms of obesity (Bell et al. 2005).

By 2006, the advance in chip genotyping technology conducted by the International HapMap project enabled the development of a new approach to investigate the genetic basis of complex diseases (Hinney and Hebebrand 2008; Day and Loos 2011). The GWAS proved to be powerful and efficient in the identification of genetic variants associated with complex diseases (Ramachandrappa and Farooqi 2011). Using many common variants, this case-control study approach screened the whole genome at much higher resolution than the approach previously described. This method operates in two stages: the first is the discovery stage in which millions of polymorphisms across the genome are tested for association with a particular trait, and then, the second stage consist in the identification of polymorphism which are associated with the trait, and subsequent tests of the presence of these polymorphisms in a new population (Marian 2012). It is now possible to identify several common polymorphisms associated with a particular trait and, like for other complex diseases, the advent of GWAS permitted to identify several loci associated with obesity (Day and Loos 2011; Loos 2012).

\subsubsection{New approaches for common obesity}

The advent of automated DNA sequencing instruments, involving advances in engineering, chemistry, molecular biology, and software, based on Sanger's methods, open a number of new opportunities (Mardis 2013). Currently, molecular diagnosis based on 
Sanger's sequencing is restricted to only a few genes as this technology is expensive, time consuming, and labor intensive. The advent of next-generation sequencing (NGS) technology provides a new method for molecular diagnosis, which consists in the identification of genetic variations within several genes at the same time (Marian 2012), promising to change the landscape of genetic testing with innovative cost-efficient methods for sensitive obesity multi-gene screening.

Only a few studies have used NGS technology to study obesity. Saeed et al. (2014) analyzed 26 susceptible genes for obesity in a sample of 39 Pakistani children with earlyonset obesity. They found two new LEPR mutations at the homozygous state: a splice site mutation in exon 15 (c.2396-1 G>T), and a nonsense mutation in exon 10 (c.1675 G>A). Sällman et al. (2013) amplified the entire region of FTO gene (412 kilo base pairs), from 524 severely obese and 527 lean Swedish children. They detected 705 single nucleotide polymorphisms, from which 19 were novel obesity-associated polymorphisms within the first intron of the FTO gene. An interesting finding was the fact that 10 of them have a stronger association with obesity $(p<0.007)$ when comparing with the commonly studied rs9939609 polymorphism $(p<0.012)$. This study concluded that within the entire region of the FTO gene the first intron was the only one associated with obesity. Bonnefond et al. (2014) searched for mutations with NGS in 40 patients, with a monogenic form of diabetes $(n=19)$ or obesity $(n=21)$, in which the causing mutation was already known. The study found the same mutations described as the phenotype cause, except for one variant (mean of 98.6\%). On the other hand novel mutations were found in 3 patients with a putative deleterious effect.

The NGS approach could be used as an efficient tool with highly sensitive screening for mutations in genes associated with obesity or other diseases. Further, sequencing the human genome can now be accomplished in the data-generation phase within two weeks at a cost of approximately US $\$ 5,000$ (Mardis 2013). However, the price for genome 
sequencing continues to decrease; in 2014, Illumina announced that will produce a new system called HiSeq X Ten that can deliver full coverage of human genomes for less than US $\$ 1,000$.

\subsection{Common loci associated with obesity-susceptibility discovered through GWAS}

The GWAS approach is the most commonly methodology used, allowing geneticists to scan numerous polymorphisms ( 0.1-5 million of polymorphisms) across the entire genome using powerful statistical methods to identify loci associated with a particular phenotype. Since the start of the GWAS era in 2005, there have been five waves of GWAS' discoveries for BMI. The first loci identified through GWAS was the fat mass and obesity-associated (FTO) gene, and currently more than 50 genetic loci have been identified as being associated with at least one obesity-related trait (Loos 2012; Sandholt et al. 2012; Xia and Grant 2013) (Figure 1).

\subsubsection{First discoveries by GWAS: FTO gene}

The first locus to be associated with obesity was the insulin-induced gene 2 (INSIG2) (Herbert et al. 2006). However, replication studies demonstrated very inconsistent results. So, the first locus unequivocally associated with obesity by a GWA study was the FTO gene (Frayling et al. 2007). Initially, Frayling et al. (2007) conducted a GWA study to test the correlation between polymorphisms across the entire human genome and type II diabetes (T2D). They found that the rs9939609 polymorphism, located in the first intron of the FTO gene was strongly associated with T2D and increased BMI. However, after adjustment for BMI, the apparent association of the polymorphism with T2D was not maintained. The effect size of FTO polymorphism on BMI is modest, with homozygous individuals for the risk allele (in this case a " $\mathrm{A}$ ") weighing on average $3 \mathrm{~kg}$ more than those homozygous for the protective allele (in this case a " $\mathrm{T}$ "), with the difference representing approximately $0.36 \mathrm{~kg} / \mathrm{m}^{2}$ (Xia and 
Grant 2013). These findings have been independently replicated and have consistently confirmed the association of rs9939609 polymorphism with the etiology of common obesity in several populations: European (Rodríguez-López et al. 2010; Albuquerque et al. 2013a), Asian (Chang et al. 2008; Hotta et al. 2008; Fang et al. 2010; Mačeková et al. 2012) and African (Grant et al. 2008; Song et al. 2008; Deliard et al. 2013), both in children and adults. Two following studies reporting other polymorphisms in the intronic FTO region were also consistently associated with severe early-onset childhood and adult obesity (rs1421085 and rs17817449) (Dina et al. 2007), and have extended the association to other obesity-related traits including body weight and waist-to-hip circumference ratio (WHR) (rs9930506) (Scuteri et al. 2007). The FTO polymorphisms were also associated with abdominal obesity, waist circumference and waist-to-hip ratio (WHR) (Heard-Costa et al. 2009; Lindgren et al. 2009), and also with body fat percentage (Kilpeläinen et al. 2011a). Although the findings replicate well, the FTO polymorphisms explain only 1-3\% of the variance in BMI (Frayling et al. 2007; Scuteri et al. 2007).

The functional mechanism underlying FTO role in obesity remains unknown, as well as the pathway underlying that role. The FTO location is a very large gene with 9 exons spanning more than 400 kilobase (kb) in the chromosome 16q12.2 (Tung and Yeo 2011). It was originally identified in 1999 in the Fused toes $(F t)$ homologue mutant, resulting in a deletion of 1.6 megabase (Mb) on chromosome 8 (Peters et al. 2002). Homozygosity of Ft mutants is embryonically lethal. To investigate the biological function of FTO gene, two mouse models were used. Homozygous FTO-/- mice introduced by Fischer et al. (2009) show postnatal growth retardation, significant reduction in fat and lean body mass compared to the wild-type animals (Church et al. 2009). In other mice model, Church et al. (2010) observed a lean phenotype in mice carrying a missense mutation in exon 6 of FTO (FTOI367F mice). These results seem to indicate that FTO could play a role in food intake control, energy expenditure and homeostasis. 
The predicted human protein consists of 505 amino acids, characterized as a 2oxoglutarate-dependent enzyme that is localized in the cell nucleus, belonging to the (2OG) oxygenases AlkB family of proteins (Gerken et al. 2007). The AlkB is a DNA repair enzyme, which catalyzes Fe(II)- and 2OG-dependent demethylation of damaged DNA substrates (van den Born et al. 2008). Recently, Jia et al. (2011) indicated that FTO also demethylates N6methyladenosine (m6A) residue in nuclear RNA. FTO variation appears to lead to an increase in energy intake (Speakman et al. 2008) by modifying hypothalamic control of appetite (Jacobsson et al. 2012). The crystal structure of FTO has recently been published and reveals the basis for its substrate specificity (Han et al. 2010).

To date, over 500 studies have been performed concerning the association of FTO polymorphisms with obesity in several populations worldwide, and more than 60 polymorphisms in this gene were significantly associated with obesity (Jacobsson et al. 2012). All these polymorphisms were found within a $47 \mathrm{~kb}$ linkage disequilibrium (LD) block encompassing parts of the first two introns as well as exon 2 of FTO gene (Fawcett and Barroso 2010). This is a region where the sequence is strongly conserved across species, were polymorphisms are highly correlated (LD $r^{2}>0.80$ in CEU of the HapMap) in Caucasian populations (Jacobsson et al. 2012).

\subsubsection{Five waves of GWAS}

Following the discovery of the FTO locus, investigators enhanced GWA studies by increasing the sample size improving statistical power to uncover additional obesitysusceptibility loci (Table 2). Subsequently, a large-scale international consortium, called the Genetic Investigation of Anthropometric Traits (GIANT) emerged. The association data of 16,876 Caucasians from seven GWAS for BMI were combined in a meta-analysis (Loos et al. 2008). This study confirmed the strong association of obesity with polymorphisms in the FTO gene, and identified one new locus near the $M C 4 R$ gene which mutations are known to be 
the common cause of extreme childhood obesity (Farooqi and O'Rahilly 2005). The MC4R was the second gene significantly associated with common obesity (Chambers et al. 2008; Loos et al. 2008). The rs 17782313 polymorphism near the MC4R gene was associated with obesity among both adults and children (Loos et al. 2008). Another polymorphism (rs12970134) near the MC4R gene was also appears to increase the risk of obesity among Europeans (Thorleifsson et al. 2009). Several polymorphisms near the MC4R gene have subsequently been found and replicated in various populations of European descents, as well as in Asians (Xi et al. 2012), African American (Xi et al. 2012), and in children and adolescents (Grant et al. 2008; Deliard et al. 2013).

In the third wave of discoveries, a meta-analysis was performed using 15 GWAS for BMI in Caucasians $(n>32,000)$ and replicated in another 14 studies for a second-stage sample of 59,082 individuals (Willer et al. 2009). They confirmed the association of the FTO and MC4R genes, and found six new genes positively associated with obesity: MTCH2, GNPDA2, KCTD15, SH2B1, NEGR1 and TMEM18. At the same time, a GWAS of 31,392 individuals, predominantly from Iceland population, found seven new genetic Loci near or in: BDNF, SEC16B, ETV5 and FAIM2, as well as FTO and MC4R genes associated with BMI (Thorleifsson et al. 2009). Four of the seven newly identified loci were common with the results from Willer et al. (2009).

In 2010, the fourth wave, the GIANT consortium expanded its GWAS stage to comprise 249,796 individuals of European origin, and reveal 18 new loci associated with BMI near or in: PRKD1, SLC39A8, GPRC5B, MAP2K5, QPCTL, RBJ, LRRN6C, FLJ35779, CADM2, TMEM160, FANCL, LRP1B, TNNI3K, MTIF3, TFAP2B, ZNF608, NRXN3, RPL27A, PTBP2 and NUDT3 (Speliotes et al. 2010). By 2011, GWAS had identified 32 genetic loci unequivocally associated with BMI.

The most recent and fifth wave expanded the GIANT meta-analysis, to comprise 263,407 individuals of European ancestry (Berndt et al. 2013). Besides confirming all $32 \mathrm{BMI}$ 
associated loci previously identified by the fourth wave, they found seven new loci: ZZZZ, RPTOR, ADCY9, GNAT2, MRPS33P4, HS6ST3 and HNF4G, explaining an additional $0.09 \%$ of the variability in BMI (Berndt et al. 2013).

To date, more than 35 loci have been found associated with the increase of BMI (explaining $~ 1-4 \%$ of the variance in BMI), while other loci correlate with abdominal obesity, establishing 13 loci associated with it, assessed by the WHR (Heid et al. 2010). Other loci, such as the Lactase gene $(L C T)$ have been associated with BMI and abdominal obesity, but more studies are required to confirm associations (Kettunen et al. 2010; Corella et al. 2011; Almon et al. 2012; Albuquerque et al. 2013b). A study identified two new loci with body fat percentage: IRS1 and the other near SPRY2 (Kilpeläinen et al. 2011b). There is a gap between explained variance due to known common polymorphisms that explain $1-4 \%$ and the estimated heritability of BMI (40-70\%). One of the main problems pointed out in GWAS is the failure to detect loci that are associated with traits whose effect sizes are too small to reach genome-wide statistical significance (false negative rate). To circumvent this "missing heritability" the genome-wide complex trait analysis (GCTA) method appears to show a multitude of low penetrance common polymorphisms, each with causal effects but too small to allow detection by GWA studies. Using this approach, Yang et al. (2011) estimate the genetic variation for $\mathrm{BMI}$ to $17 \%$ and in a recent analysis of twin studies revealed that $37 \%$ of BMI could be explained by additive effects of multiple common polymorphisms (Llewellyn et al. 2013). Finally, a recent study found that BMI-associated FTO variants interact with the promoter region of iroquois homeobox $3(\operatorname{IRX} 3)$ gene in the human, mouse and zebrafish genomes (Smemo et al. 2014). They also found that in Irx3-deficient mice, there is a reduction in body weight of 25 to $30 \%$. However, the IRX3 gene had not been previously identified as associated with BMI in a GWA study. All these data confirmed the complexity of the genetics underlying obesity. 


\subsection{Testing adult-discovered loci in children}

Childhood obesity is a major health problem in developing countries throughout the world. Most of obesity susceptible genes were found in studies with adults, which prompted an effort to replicate findings in studies with children (Zhao et al. 2011; Albuquerque et al. 2013a; Deliard et al. 2013). Knowledge of the genetic risk factors of obesity in children could be used as a first step to develop possible prevention measures. The FTO locus remains the most replicated gene and the strongest gene associated with obesity susceptibility, both in adults and children (Albuquerque et al. 2013a; Deliard et al. 2013; León-Mimila et al. 2013). Genes TMEM18 and GNPDA2 were also associated with obesity susceptibility, with a similar effect of the FTO gene (Zhao and Grant 2011). The remaining loci with evidence for association were INSIG2, MC4R, NEGR1, BDNF and KCTD15 (Zhao and Grant 2011; Mitchell et al. 2013).

In the GIANT meta-analysis of adult BMI in a pediatric European American sample, Zhao et al. (2011) examined 32 genetic loci in 1,097 obese cases and 2,760 lean controls, aged between 2 and 18 years old. They found evidence of associations with nine of these loci, namely at FTO, TMEM18, NRXN3, MC4R, SEC16B, GNPDA2, TNNI3K, QPCTL, and BDNF. Overall, 28 of the 32 loci showed directionally consistent effects to that of the adult BMI meta-analysis.

Another similar report by the Early Growth Genetics (EGG) consortium investigated the effect of established adult BMI with two recently associated loci with childhood obesity (HOXB5 and OLFM4 genes) (Bradfield et al. 2012) in a Greek adolescents cohort (Ntalla et al. 2013). The genetic risk score of the 34 (GRS-34) variants was calculated and found that variants at the FTO, TMEM18, FAIM2, RBJ, ZNF608 and QPCTL loci produced nominal evidence for association with BMI and/or obesity risk. Overall, 27 out 34 variants showed consistent effects with those reported by large-scale meta-analyses adult BMI.

These results showed clearly that these obesity-conferring variants operate early in life, 
suggesting that individual preventative lifestyle intervention in childhood could be important to obesity development.

\subsection{GWAS-related investigations in other ethnicities}

There are remarkable disparities in the prevalence of obesity between ethnic groups. To date most of GWAS reports published have been performed in populations of European origin. Only one study identified, at the first discovery stage, a locus near MC4R gene associated with waist circumference and insulin resistance in a cohort of South Asian population (Chambers et al. 2008). This could be partly due to the fact that some susceptible loci only affect a specific ethnic group, while others might affect any ethnic group. Indeed, the human genetic architecture differs across ethnicities, which is well illustrated by differences in linkage disequilibrium (LD), whereas haplotype blocks vary only somewhat among human populations (Slatkin 2008).

As a case in point, FTO locus have consistently correlated with BMI and risk of obesity in populations of African (Grant et al. 2008; Song et al. 2008; Hennig et al. 2009; Deliard et al. 2013), Asian (Chang et al. 2008; Hotta et al. 2008; Fang et al. 2010; Mačeková et al. 2012) and Pacific-Islander (Ohashi et al. 2007) ancestry. Despite the fact that effect sizes were similar to those observed in white European populations, the risk of allele frequency varies substantially: $\sim 25 \%$ in Asian, $\sim 45 \%$ in white Europeans and range of $\sim 7$ to $18 \%$ in African origin (Hassanein et al. 2010).

Two recent independent meta-analysis were performed in both East Asians and African populations (Wen et al. 2012; Monda et al. 2013): Wen et al. (2012) performed a metaanalysis using 27,715 individuals, followed by in silico and de novo replication studies in a further 37,691 and 17,642 individuals of East Asians, respectively. Seven previously identified loci were detected (FTO, SEC16B, MC4R, GIPR-QPCTL, ADCY3-RBJ, BDNF and MAP2K5) and three new loci were uncovered, near or in CDKAL1, PCSK1 and GP2 genes. 
Data also implicated three loci, GNPDA2, TFAP2B (previously identified) and PAX6, which all reached the genome-wide significance threshold. A recent meta-analysis was conducted to examine the association of $>3.2$ million polymorphisms with BMI in 39,144 adults of African ancestry (Monda et al. 2013). It identified one new locus at 5 q33 (GALNT10, rs7708584 polymorphism) and another at 7p15, when data from the GIANT consortium was included (MIR148A-NFE2L3, rs10261878 polymorphism). They also found evidence of an association at $6 q 16$ (KLHL32, rs974417 polymorphism) in African-ancestry sample. Overall, 32 of the 36 previously established BMI variants showed consistent effect in this GWAS. The 36 known $\mathrm{BMI}$ loci explain in average $1.30 \%$ of the variance in BMI of African ancestry compared with $1.67 \%$ and $1.25 \%$ in European and Asian ancestry populations, respectively (Monda et al. 2013). More recently, Tan et al. (2014) replicated 6 confirmed obesity genes (FTO, CTNNBL1, ADRB2, LEPR, PPARG and UCP2 genes) in 8 different samples from different ancestries (five Caucasian, one Chinese, one African-American and one Hispanic population). Regarding only the FTO gene they found 35 polymorphisms significantly associated with obesity in Caucasian population. However, all of them showed limited or no evidence of associations with obesity in the other ethnic groups.

Association studies across different populations can help us to define more precisely which loci or variants could play a role in the obesity etiology, and help to understand the genetic and environmental factors that could contribute to obesity. The discovery of new loci in replication studies at established loci found in other populations reflects differences in allele frequency and effect size. Further studies will be needed to test the biological function at the associated loci.

\subsection{Obesity risk-allele scores}

As noted, several GWAS have identified a large number of obesity susceptibility loci. Nevertheless, the major part of these studies only identified single genetic loci associated 
with obesity. It has indeed been demonstrated that combining information from all these obesity loci into a genetic risk-allele scores (GRS) could be a convenient way to summarize a risk-associated variation across the genome (Horne et al. 2005) and better when individual genetic effects are moderate (Belsky et al. 2013). The simplest way to calculate a GRS is by summing the number of accumulated risk alleles associated with the disease. Using this approach, Zhu et al. (2014) analyzed 28 BMI-associated polymorphisms in a sample of Han Chinese and found 26 nominally associated with BMI. To assess the combined effect of all polymorphisms studied with BMI, they create a GRS which was associated with increased risk of obesity (OR=1.06; $\mathrm{Cl} 95 \%$ : 1.03-1.10), and each additional $\mathrm{BMI}$-increasing allele in the GRS was associated with $0.11 \mathrm{~kg} / \mathrm{m}^{2}$ higher BMI $\left(p=1.54 \times 10^{-7}\right)$. Willer et al. (2009) found effect sizes between $0.06 \mathrm{~kg} / \mathrm{m}^{2}$ to $0.33 \mathrm{~kg} / \mathrm{m}^{2}$ per allele in BMI changes and that account for $0.40 \%$ of the variance of BMI analyzing six loci together (TMEM18, KCTD15, GNPDA2, SH2B1, MTCH2 and NEGR1). When they included the FTO and MC4R genes in the combined effect, the variance increases to $0.84 \%$. Similar results have also been found in other studies trying to explain the variance of BMI. Combining 12 polymorphisms in a sample of 20.431 of European descent, the GRS obtained by Li et al. (2009) explained 0.9\% of BMI variation. Apart the nominally association between 15 polymorphisms located in or near the INSIG2, FTO, MC4R, TMEM18, GNPDA2, NEGR1, BDNF, KCTD15, and 1q25 genes with BMI, Zhao et al. (2009) explained $1.12 \%$ of the total variation for BMI z-score in a sample of children of European ancestry. In other sample of European descent González et al. (2014) create a GRS including six polymorphisms located in the FTO, TFAP2B, SEC16B, ETV5 and SH2B1 genes and found that individuals carrying $\geq 7$ risk-alleles had 3.1 (OR=3.11; Cl95\%: 1.58-6.61) times increase in the odds of developing the obese phenotype. Individually, each risk allele conferred an estimated increased risk of 1.69 (OR: 1.69; Cl95\%: 1.46-1.97) times to develop obesity.

The use of a combined genetic score is considered as a better tool to determine the 
susceptibility of a common trait, than using each genetic locus alone. This is particularly more evident when the allele score consists either of many common polymorphisms with small effects, or of rare polymorphisms (Belsky et al. 2013). Generally, when several polymorphisms are combined into the same allele score, the score may explain a considerable proportion of variation in the risk factor, even if none of the polymorphisms individually does. In complex diseases it is likely that the effects of different genetic loci related to obesity operate in an interactive fashion. Future research should investigate this possibility using classification or regression tree analyses, which are well suited to detecting complex non-linear interactions. The identification of the complex interplay among all genes in the genome-wide context is essential to unravel the molecular mechanisms in the obesity etiology. However, as previously demonstrated there are differences between populations regarding to alleles frequencies. Belsky et al. (2013) sought to develop a GRS for obesity using results obtained in 16 previously published GWAS in European descent samples. Analyzing 32 locus they found a significantly predictor of BMI and obesity among Europeans. However, the predictive effects for this GRS did not replicate among African Americans due particularly to the differences in risk-allele distributions.

\subsection{Epigenetics}

Epigenetic regulation of gene expression emerged in the last few years as a potential factor that might explain individual differences in obesity risk (Campión et al. 2009). Epigenetics can be defined as heritable changes that are mitotically stable (and potentially meiotically) and affect gene function but do not involve changes in the DNA sequence (Bird 2002). At the molecular level, epigenetic markers include genomic DNA methylation, changes in chromatic organization by histone modifications, the non-coding micro RNAs (miRNA), genomic imprinting, non-covalent mechanisms, and other nuclear proteins that are critical for epigenetic gene regulation (Kim et al. 2009). Currently, there is a growing interest 
in the study of the relations between genetic variation, epigenetic variation, and disease simultaneously.

Emerging studies have characterized the potential mechanisms by which epigenetic factors could increase the risk for obesity (Table 3). Moreover, unlike DNA genotypes, epigenetic markers can change during lifetime, and have a heterogeneous distribution in tissues. DNA methylation is the most well know epigenetic marker, which has been proposed as a new generation of biomarkers. It is a biologic process that consists of the addition of a methyl group at the carbon-5 position of cytosine, in the context of the CpG dinucleotides, and usually associated with gene silencing in the promoter regions (Costello and Plass 2001; Bird 2002). The universal methyl donor is DNA methyltransferases (Dnmts) that maintain the cellular DNA methylation patterns (Campión et al. 2009). Despite the high number of DNA methylation candidate genes and some epigenome-wide association studies (EWAS), most of the associations have not yet been replicated in other samples to further confirm and establish whether those loci are reliably associated with obesity.

Using a genome wide approach, obesity has been related to changes in DNA methylation status in peripheral blood leukocytes of lean and obese adolescents for two genes. In the ubiquitin-associated and SH3 domain-containing protein A (UBASH3A) gene, a CpG site showed higher methylation levels in obese cases, and one $\mathrm{CpG}$ site in the promoter region of Tripartite motif-containing 3 (TRIM3) gene, showed lower methylation levels in the obese cases (Wang et al. 2010). In a recent work, Godfrey et al. (2011) measured the methylation status of $68 \mathrm{CpGs} 5^{\prime}$ from five candidate genes in umbilical cord tissue DNA from healthy neonates, and found that methylation higher levels within promoter region of retinoid $\mathrm{X}$ receptor-a $(R X R A)$ gene, measured at birth, was strongly correlated with greater adiposity in later childhood (Godfrey et al. 2011). A positive correlation between maternal $\mathrm{BMI}$ and promoter methylation in peroxisome proliferator-activated receptor-gamma coactivator 1alpha (PPARGC1A), a gene encoding a transcriptional coactivator of the 
peroxisome proliferator-activated receptor (PPAR) $\alpha$ and $\mathrm{y}$, playing an essential role in energy homeostasis, was observed when analyzing promoter genomic DNA from umbilical cord newborns (Gemma et al. 2009).

The obesity risk allele of FTO has been associated with higher methylation of sites within the first intron of the FTO gene, suggesting an interaction between genetic and epigenetic factors (Gemma et al. 2009). Moreover, Almén et al. (2012) determined the methylation profile on a genome-wide scale by sampling DNA from peripheral whole blood in female preadolescents. The sample included obese and a normal weight groups, both of which contains homozygous carriers of both the FTO normal and risk alleles (rs9939609). They analyzed how the risk allele for rs9939609 polymorphism affects the methylation status of sites related to other genes (KARS, TERF2IP, DEXI, MSI1, STON1 and BCAS3), showing that the FTO gene may influence the methylation level of other genes (Almén et al. 2012).

A study examined the MC4R gene, which is associated with common and morbid obesity and encodes for a protein that is a membrane-bound receptor and member of the melanocortin receptor family controlling food intake and energy expenditure. Mouse genomic DNA of brain tissue was examined to determine the methylation status of the MC4R exon. Results indicated that methylation of the CpGs was decreased in response to high-fat diet (Widiker et al. 2010). A study examining whether a high-energy diet may affect promoter methylation of $L E P$ gene, encoding an adipokine involved in body weight and food intake regulation, showed in DNA isolated from retroperitoneal adipocytes in rats that leptin methylation pattern can be influenced by diet-induced obesity (Milagro et al. 2009). Zhao et al. (2013) demonstrated that promoter hypermethylation in the serotonin transporter gene (SLC6A4) was associated with an increase in BMI, body weight and waist circumference. Xu et al. (2013) studied 470,000 CpG sites from 48 obese and lean youth African-American (1420 years-old); they found a differential variability in $C p G$ sites which was more variable in 
obese than lean subjects, constituting an important feature of obesity related with methylation changes. In another recent EWA study, analyzing 476,753 CpG sites to evaluate the possible alteration of DNA methylation patterns after a six-month exercise intervention. A global DNA methylation changes were found in 17,975 individual CpG sites altering the levels of DNA methylation in response to physical activity (Rönn et al. 2013).

Thus, most of these DNA methylation sites need to be confirmed as being associated with obesity, taking into account the tissue sampled, obesity history, and eating behaviors. However, the high number of new studies concerning obesity epigenetics will undoubtedly permit the confirmation some of these associations, thereby establishing an epigenetic basis for human obesity. Interestingly, one recent work of genome wide analysis revealed that carriers of the FTO risk allele (rs9939609) had a significant differential methylation level in 6 Ioci (KARS, TERF2IP, DEXI, MSI1, STON1 and BCAS3) compared to non-carriers controls (Widiker et al. 2010). This work could elucidate the mechanisms underlying the association of obesity with genetic variants, possibly due to epigenetic factors.

microRNAs

The gene expression in humans is precisely controlled in cellular, temporal, and condition specific manner. Because microRNAs (miRNAs) have been shown to be important in gene regulation, it is not surprising that they have been implicated in the development of obesity (Williams and Mitchell 2012). Therefore, the understanding of the regulatory mechanisms of gene expression can shed some light on the underlying mechanisms causing obesity. miRNAs are endogenous short single-stranded non-protein-coding RNAs with about $21 / 25$ nucleotides in length which are involved in post-transcriptional regulation of gene expression by partially complementary binding to the $3^{\prime}$ untranslated region ( $3^{\prime}$ UTR) of target mRNAs (Ambros 2004; Bartel 2004).

Several miRNAs expression patterns have been profiled during adipocyte differentiation 
(Kajimoto et al. 2006; Xie et al. 2009; Ortega et al. 2010), others have been linked to adipocyte phenotype, and other obesity parameters (Kajimoto et al. 2006; Takanabe et al. 2008; Klöting et al. 2009; Xie et al. 2009; Ortega et al. 2010; Heneghan et al. 2011; Keller et al. 2011; Ortega et al. 2013) (Figure 2). For example, miR-21 was strongly expressed in human adipose tissue and positively correlated with BMI (Keller et al. 2011). These studies revealed that miRNAs may represent biomarkers for obesity, and could also be implicated in the molecular mechanisms leading to this disease. However, further studies are needed to elucidate the effect of miRNAs and other epigenetic mechanisms in the etiology of obesity.

Continuous advances in research show promising results about the implication of epigenetics mechanisms in the etiology of obesity. Epigenetics has shown that our genes are not the only factor to determine our phenotype and that our behaviors can alter the expression of our genotypes. However, additional research is needed, particularly with regard to which cell types should be explored in EWAS.

\subsection{Evolutionary explanations for obesity}

Like all other life on earth, humans have evolved. The theory of evolution suggests that one of the evolutionary forces behind natural selection, first described by Charles Darwin in 1859, was the differential selection of individuals that exhibit a determine phenotypic trait that could lead to an increase in fitness. As a result, these individuals were better adapted to their environment than others and, thus, would have greater success reproducing. However, other forces like genetic drift, gene flow and mutation also account for human evolution.

The evidence for a genetic component of obesity has been well established (Bell et al. 2005). The question is; how has natural selection favored the spread of genes that increase risk for an obese phenotype and how has this predisposition to obesity evolved? Answers to these questions should advance understanding the etiology of obesity. However, our knowledge about the evolution of body-weight regulation mechanisms in human remains 
incomplete. Nevertheless, three different types of evolutionary perspective have been proposed in an attempt to address these questions (Speakman 2013).

The first hypothesis is that the modern genetic predisposition to obesity was adaptive in the past, when storing large amounts of fat could have been selectively advantageous. The most popular adaptive interpretation of obesity was proposed by Neel (1962) and is called the "thrifty gene" hypothesis. It explain the prevalence of obesity and diabetes in modern societies due to a change in lifestyle from that of Paleolithic hunters-gatherers to a subsistence based on agriculture, a pattern characterized by more sedentary occupations. The basis of this hypothesis states that during evolution of the modern human, genes that promoted efficient fat accumulation would be extremely advantageous for primitive humans, because they allow their holders to survive famine periods (Speakman 2006). In modern societies, where food supply is always available, such genes are disadvantageous and the result is widespread obesity (Speakman 2006; 2013).

Studies were conducted to try and identify genes with a positive selection. A study lead by Myles et al. (2011), suggested that the high frequency of the risk allele of the Gly482Ser variant in the PPARGC1A gene in Polynesians populations remains a thrifty allele in the Pacific populations. Another variant, the $P C-1 \mathrm{G} \ln 121$, was also considered as a possible thrifty gene supported by studies in African and other groups (Rey et al. 2012). A recent study provides evidence for a positive selection of TRIB2 gene, which influences visceral fat accumulation in East Asians (Nakayama et al. 2013). In addition to these few examples showing a possibly positive selection in our evolutionary history with metabolic traits, others loci have been extensively studied, one of them being the $L C T$ gene, at 7,000 years bp, which is considered a prototypic example of selective advantage leading to rapid human evolution compatible with the agricultural innovations (Bersaglieri et al. 2004). In European populations, the $-13910 C>T$ (LCT) polymorphism has been associated with the persistence of the lactase enzyme in adulthood: individuals carrying the CC genotype possess insufficient 
enzyme activity in intestinal cells and are classified as lactase non-persistence (i.e., show lactose intolerance), which is considered the ancestral condition in humans, whereas individuals carrying at least one $\mathrm{T}$ allele are considered lactase persistent (Enattah et al. 2002). Nevertheless, this adaptive hypothesis reveals some problems: if accumulating extra adipose tissue was advantageous in the past populations, many people lacking these thrifty genotypes in modern society do not develop the obese phenotype, despite the environmental change favoring fat storage. On the other hand, population genetic models predict that thrifty genes would not have sufficient advantage or even time to spread in the human population (Speakman 2004).

A second explanation emerged to highlight the evolution of the obese phenotype. The maladaptive viewpoint suggests that obesity is not adaptive and may never even have existed in human evolution history, except in some individuals with unusual genetic modifications such as the monogenic forms of obesity (Speakman 2013). Nevertheless, genes that actually predispose us to obesity could be favored as a maladaptive by-product of positive selection on some other advantageous trait. One example of this maladaptive interpretation is the work that suggests that obesity could result from individual differences in brown adipose tissue (Speakman 2013).

Finally, a third explanation for the evolutionary selection favoring obesity is that most mutations in the obesity susceptibility genes are neutral and have been drifting over evolutionary time (Speakman 2008; 2013). The neutral theory of molecular evolution, postulates that most evolutionary changes at the molecular level is not caused by natural selection, but by genetic drift (Kimura 1983). According to this theory, the majority of genetic variation observed within and between species is selectively neutral, i.e. does not affect the fitness of individuals. On the other hand, according to the theory of natural selection, most of the genetic variation observed in populations affect the fitness of individuals and thus is subject to selection (Nielsen 2005). This new "drifty genes" 
hypothesis is a non-adaptive scenario providing an explanation for why some individuals get obese while others remain obesity resistant (Speakman 2008; 2013).

There are three different perspectives that attempt to explain how human obesity evolved; however, none of them provide a compelling answer to this complex phenotype. Understanding human evolution will help us to understand modern human behavior and traits.

\subsection{Prevention and treatment based on genotyping}

\subsubsection{Nutrigenetics}

Nutrition is one of the lifestyle factors contributing to the development and progression of obesity. An appropriate intake of energy and nutrients has been commonly accepted to prevent weight gain. Furthermore, epigenetics studies have demonstrated that several nutrients and bioactive food could play a role in the complex machinery involving the interaction between genome and the epigenome, which regulate gene expression (McKay and Mathers 2011). The ingestion of these nutrients introduces some bioactive components that have signal molecules that carry information from the external environment (Milner 2004). Many dietary components can modulate epigenetic phenomena by inhibiting enzymes such as DNA methyltransferases and histone deacetylases (McKay and Mathers 2011), with the most well know vitamin B-12 and folate providing methyl groups for DNA methylation reaction (Brunaud et al. 2003; Choi et al. 2004). New research has attempted to understand the variability in metabolic responses to diet and food components, which could affect health. Nutrigenetics recognizes the effect of genetic variation on nutrient requirements, while nutrigenomics study the interaction between nutrients and genes (Steemburgo et al. 2009). These areas aim to develop diagnostic tools that can "read" genetic susceptible loci in order to offer a personalized diet, taking into account the individual needs. Interactions among genetic loci and diet were found for obesity in 
interleukin-6 (IL-6), with daily food intake, peroxisome proliferator-activated receptor gamma 2 (PPAR-gama2) and FTO with fat intake (Steemburgo et al. 2009). The Mediterranean diet is known to be rich in folates, which is crucial for the DNA methylation status. Ortega-Azorín et al. (2012) found a significant gene-diet interaction of the FTO rs9939609 and MC4R rs17782313 polymorphisms with type 2 diabetes depending on diet, in which the Mediterranean diet counteracts the genetic predisposition. A cross-sectional study found that individuals carrying both AA risk allele of the rs9939609 polymorphism were positively associated with a high intake of total fat (>34\% energy) and low fiber consumption ( $<16 \mathrm{~g} /$ day), independently of BMI (Steemburgo et al. 2013). It has also been reported in a recent study that obesity susceptibility genes (FAIM2, FLJ35779, FTO, LRRN6C, $R B J$, and $S E C 16 B$ ) were found to interact with dietary carbohydrates (sugar-sweetened beverages) to increase BMI when one or more servings are consumed per day (Qi et al. 2012). Other two genes: $\beta$-adrenergic receptor 2 (ADRB2) and MC4R were also suggested being related with carbohydrate intake (Steemburgo et al. 2009).

During pregnancy and early postnatal life, an individual can be programmed for nutritional thrift to adapt and survive in an environment scarce in resources. In 2008, Heijmans et al. (2008) studied the degree of methylation at five DNA sites in the insulin-like growth factor 2 (IGF2) gene on the population exposed to the Dutch famine of 1944-1945. Prenatal exposure to the Dutch famine was associated with the risk of obesity.

Kucharski et al. (2008), provided evidence that epigenetic information could be differentially altered by the nutritional input in honeybee (Apis mellifera). Moreover, they found that epigenetic modifications could provoke profound changes in developmental fates with implications in reproductive and behavioral status. When bee larvae are fed royal jelly, it turns off the expression of DNA Dnmt3 and other genes are expressed, turning some of them into a queen, whereas bee larvae that are not fed royal jelly, Dnmt3 remains active and the larval development produces the worker variety of bees. 
A dietary intervention could be helpful in prevention as a potential instrument that can complement dietary advice. However, there are some limitations concerning nutrigenetics applications, such as: lack of studies analyzing the evidence of common polymorphisms studied, polymorphisms differ on ethnic background, and the high cost of the genetic analyses for a personalized medicine. More generally, compliance with nutrient based recommendations, such as reducing intake of fat and sugar, has been very poor.

\subsubsection{Physical activity-genotype interactions}

Physical activity is another component involved in the heterogeneous set of factors contributing to obesity. Regular exercise is one of the most promising behavioral candidates for preventing and reducing weight gain beyond other health and psychological benefits (Richardson et al. 2014). However, several studies have provided evidence that the propensity to be physically active has also a strong genetic component in both animals and humans (Herring et al. 2014). In humans, physical activity has been shown to aggregate in families; more active parents have more active children relative to inactive parents (Moore et al. 1991). The physical activity heritability ranges from $9 \%$ in Mexican-American families, to almost $80 \%$ in European twins (Herring et al. 2014). The FTO locus, the most well studied in common obesity showed evidences of a gene-by-physical-activity interaction with the obese phenotype in adults of European origin (Kilpeläinen et al. 2011a; Ahmad et al. 2013). Investigators observed that the estimated effect of the A risk allele of rs9939609 increased the odds of obesity by 1.23 -fold/allele, but attenuated by $27 \%$ in physical active adults $\left(p_{\text {interaction }}=0.001\right)$ (Kilpeläinen et al. 2011a). The meta-analysis conducted by Ahmad et al. (2013) showed similarly a statistical significant GRS x physical activity interaction effect estimate $\left(p_{\text {interaction }}=0.015\right)$. Common polymorphisms in the $M C 4 R$ gene were also found associated with self-reported physical inactivity in French-Canadian families and MexicanAmericans (Loos et al. 2005; Cai et al. 2006). 
Another variant, the GIn223Arg polymorphism located in LEPR gene, was found to be associated with lower $24 \mathrm{~h}$ energy expenditure and physical activity levels in individual homozygotes for the Arg223 allele compared to Gln homozygotes in Pima Indians population (Stefan et al. 2002). Results obtained in a recent meta-analysis of 111,421 adults of European ancestry conducted by Ahmad et al. (2013), support the interaction effect between physical activity and a genetic risk score (combining 12 polymorphisms) in obesity disposition $\left(p_{\text {interaction }}=0.015\right)$.

A study performed in a heterogeneous adolescent cohort examined the association of adiposity-related single-nucleotide polymorphisms and moderate to vigorous physical activity with BMI (Richardson et al. 2014). Authors found three polymorphisms, in which moderate to vigorous physical activity interact with ethnicity to explain variation in BMI: two in European American at GNPDA2 and FTO genes, one in Hispanic American at LZTR2/SEC16B gene and none in African American. Ethnicity-pooled meta-analysis showed the increase in BMI Z-score per copy of the FTO, GNPDA2, POC5 and TFAP2B risk alleles in 0.4 units greater in individuals with low vs. high moderate to vigorous physical activity. So, higher levels of physical activity may attenuate the influence of obesity susceptibility polymorphisms on BMI during adolescence. It appears that some variation in our DNA could contribute to the variation in the physical activity level. The use of genomics-based information could be used to change our risk behavior.

\subsubsection{Drug genotype interaction}

The use of drugs as a treatment option for obesity could be indicated for individuals with a BMI >30 with existing co-morbidities such as diabetes, dyslipidemia or hypertension (O'Connor and Swick 2013). In the last decade, with the discovery that some drugs were affected by hereditarily variation, the concept of "pharmacogenetics" emerged (Cascorbi et al. 2013). This new field focuses on the study of polymorphisms within one or more 
candidate genes for associations with pharmacologic phenotypes. So, common polymorphisms may alter the response to pharmacotherapy affecting drug metabolism, drug transport or drug targets (Cascorbi et al. 2013; O'Connor and Swick 2013). Relating to obesity, at least 35 loci were validated as being associated with BMI and the advent of GWAS and next generation sequencing will likely lead to the identification of additional genetic biomarkers. Until now, only three obesity-related drugs were approved for continuous use in the United States of America (USA): orlistat (Xenical ${ }^{\circledast}$, Alli®), lorcaserin $\mathrm{HCL}$ (Belviq $\left.{ }^{\circledR}\right)$, and phentermine and topiramate extended release (Qsymia $\left.{ }^{\mathrm{TM}}\right)\left(\mathrm{O}^{\prime}\right.$ Connor and Swick 2013). Orlistat is a drug that alters metabolism by inhibiting the gastro-intestinal absorption of triglycerides (Ravussin and Bouchard 2000). Lorcaserin HCL and Phentermine are drugs that act centrally as an appetite suppressant (Cosentino and Conrad 2013; O'Connor and Swick 2013).

In the future, it may be possible to determine which sub-populations will respond optimally to particular doses of drugs, allowing more effective personalized pharmacologic intervention. To achieve this end, it would be idea if pharmacogenetic studies could identify differences in drug response and tolerability, and investigate gene regulation, epigenetic modifications, and DNA-protein interactions that may explain individual differences in responses to drugs beyond genetic variation. Ultimately, it will also be necessary for clinical trials to evaluate pharmacologic interventions that are guided by genetic tests.

\subsection{Final remarks}

Obesity is a complex phenotype resulting from the interaction of several internal and external factors. Although most scientists and clinicians now acknowledge that genes contribute to obesity, at this point relatively little is known regarding the specific loci involved and the mechanism by which they lead to the expression of obesity. Like many other complex human traits, environmental factors also play a major role in the etiology of 
obesity. Evidence suggests that interactions between genetic and environmental factors may contribute to the epigenetic changes. These epigenetic factors have recently emerged as important players for the obesity phenotype. Moreover, the importance of gene expression and microRNAs were also associated with obesity. Altogether, these factors elucidate the complexity of obesity, and the importance of understanding all of the relevant vulnerability factors in order to develop new therapeutic approaches for the disease. Personalized medicine becomes increasingly a potential instrument due to the recent advance in nutrigenetics or nutrigenomics. However, the use of complement dietary advice in primary care and prevention based on the susceptibility of patients to develop obesity remain limited. For now, there is a lack of evidence in the interaction between some polymorphisms and food consumption. Although remarkable advances in our understanding of the factors that give rise to obesity have occurred, further research on the etiology and probable genetic nature of obesity is needed.

\section{Conflict of interests}

All the authors recognize and disclose to have no conflict of interest to declare.

\section{Funding}

David Albuquerque as a PhD grant (SFRH/BD/68774/2010) from Fundação para a Ciência e a Tecnologia (FCT).

\section{References}

Ahmad S, Rukh G, Varga TV, Ali A, Kurbasic A, Shungin D, Ericson U, Koivula RW, Chu AY, Rose LM, et al. Gene $\times$ physical activity interactions in obesity: combined analysis of 111,421 individuals of European ancestry. PLoS Genet. 2013; 9(7): e1003607. 
Albuquerque D, Nóbrega C, Manco L. Association of FTO polymorphisms with obesity and obesity-related outcomes in Portuguese children. PLoS One. 2013a; 8(1): e54370.

Albuquerque D, Nóbrega C, Manco L. The lactase persistence -13910C>T polymorphism shows indication of association with abdominal obesity among Portuguese children. Acta Paediatr. 2013b; 102(4): e153-e157.

Albuquerque D, Nóbrega C, Rodríguez-López R, Manco L. Association study of common polymorphisms in MSRA, TFAP2B, MC4R, NRXN3, PPARGC1A, TMEM18, SEC16B, HOXB5, and OLFM4 genes with obesity-related traits among Portuguese children. J Hum Genet. 2014; 59: 307-313.

Almén MS, Jacobsson JA, Moschonis G, Benedict C, Chrousos GP, Fredriksson R, Schiöth HB. Genome wide analysis reveals association of a FTO gene variant with epigenetic changes. Genomics. 2012; 99(3): 132-137.

Almon R, Alvarez-Leon EE, Serra-Majem L. Association of the European lactase persistence variant (LCT-13910 C>T polymorphism) with obesity in the Canary Islands. PLoS One. 2012; 7: e43978.

Ambros V. The functions of animal microRNAs. Nature. 2004; 431: 350-355.

Bartel DP. MicroRNAs: genomics, biogenesis, mechanism, and function. Cell. 2004; 116: 281297.

Bates SH, Myers MG. The role of leptin receptor signaling in feeding and neuroendocrine function. Trends Endocrinol Metab. 2003; 14: 447-452.

Beckers S, Mertens I, Peeters A, Van Gaal L, Van Hul W. Screening for melanocortin-4 receptor mutations in a cohort of Belgian morbidly obese adults and children. Int J Obes (Lond). 2006; 30: 221-225.

Bell AC, Kremer PJ, Magarey AM, Swinburn BA. Contribution of 'noncore' foods and beverages to the energy intake and weight status of Australian children. Eur J Clin Nutr. 
2005; 59: 639-645.

Bell CG, Finer S, Lindgren CM, Wilson GA, Rakyan VK, Teschendorff AE, Akan P, Stupka E, Down TA, Prokopenko I, et al. Integrated genetic and epigenetic analysis identifies haplotype-specific methylation in the FTO type 2 diabetes and obesity susceptibility locus. PLoS ONE. 2010; 5(11): e14040.

Bellisari A. Evolutionary origins of obesity. Obes Rev. 2008; 9: 165-180.

Belsky DW, Moffitt TE, Sugden K, Williams B, Houts R, McCarthy J, Caspi A. Development and evaluation of a genetic risk score for obesity. Biodemography Soc Biol. 2013; 59(1): 85-100.

Berndt SI, Gustafsson S, Mägi R, Ganna A, Wheeler E, Feitosa MF, Justice AE, Monda KL, Croteau-Chonka DC, Day FR, et al. Genome-wide meta-analysis identifies 11 new loci for anthropometric traits and provides insights into genetic architecture. Nat Genet. 2013; 45(5): 501-512.

Bersaglieri T, Sabeti PC, Patterson N, Vanderploeg T, Schaffner SF, Drake JA, Rhodes M, Reich $D E$, Hirschhorn JN. Genetic signatures of strong recent positive selection at the lactase gene. Am J Hum Genet. 2004; 74(6): 1111-1120.

Bird A. DNA methylation patterns and epigenetic memory. Genes Dev. 2002; 16(1): 6-21.

Bradfield JP, Taal HR, Timpson NJ, Scherag A, Lecoeur C, Warrington NM, Hypponen E, Holst C, Valcarcel B, Thiering E, et al. A genome-wide association meta-analysis identifies new childhood obesity loci. Nat Genet. 2012; 44: 526-531.

Brunaud L, Alberto JM, Ayav A, Gérard P, Namour F, Antunes L, Braun M, Bronowicki JP, Bresler L, Guéant JL. Vitamin B12 is a strong determinant of low methionine synthase activity and DNA hypomethylation in gastrectomized rats. Digestion. 2003; 68: 133-140.

Burgess S, Thompson SG. Use of allele scores as instrumental variables for Mendelian randomization. Int J Epidemiol. 2013; 42(4): 1134-1144. 
Cai G, Cole SA, Butte N, Bacino C, Diego V, Tan K, Göring HH, O'Rahilly S, Farooqi IS, Comuzzie AG. A quantitative trait locus on chromosome $18 q$ for physical activity and dietary intake in Hispanic children. Obesity (Silver Spring). 2006; 14: 1596-1604.

Campión F, Milagro F, Martínez J. Etiology and Pathophysiology: Individuality and epigenetics in obesity. Obes rev. 2009; 10: 383-392.

Cascorbi I, Bruhn O, Werk AN. Challenges in pharmacogenetics. Eur J Clin Pharmacol. 2013; 69(Suppl 1): S17-S23.

Chambers JC, Elliott P, Zabaneh D, Zhang W, Li Y, Froguel P, Balding D, Scott J, Kooner JS. Common genetic variation near MC4R is associated with waist circumference and insulin resistance. Nat Genet. 2008; 40: 716-718.

Chang YC, Liu PH, Lee WJ, Chang TJ, Jiang YD, Li HY, Kuo SS, Lee KC, Chuang LM. Common variation in the fat mass and obesity-associated (FTO) gene confers risk of obesity and modulates BMI in the Chinese population. Diabetes. 2008; 57: 2245-2252.

Choi SW, Friso S, Ghandour H, Bagley PJ, Selhub J, Mason JB. Vitamin B-12 deficiency induces anomalies of base substitution and methylation in the DNA of rat colonic epithelium. J Nutr. 2004; 134: 750-755.

Church C, Lee S, Bagg EA, McTaggart JS, Deacon R, Gerken T, Lee A, Moir L, Mecinović J, Quwailid MM, et al. A mouse model for the metabolic effects of the human fat mass and obesity associated FTO gene. PLoS Genet. 2009; 5: e1000599.

Church C, Moir L, McMurray F, Girard C, Banks GT, Teboul L, Wells S, Brüning JC, Nolan PM, Ashcroft FM, et al. Overexpression of Fto leads to increased food intake and results in obesity. Nat Genet. 2010; 42: 1086-1092.

Clément K, Ferré P. Genetics and the pathophysiology of obesity. Pediatr Res. 2003; 53: 721 725.

Corella D, Arregui M, Coltell O, Portolés O, Guillem-Sáiz P, Carrasco P, Sorlí JV, Ortega-Azorín 
C, González JI, Ordovás JM. Association of the LCT-13910C>T polymorphism with obesity and its modulation by dairy products in a Mediterranean population. Obesity (Silver Spring). 2011; 19: 1707-1714.

Cosentino G, Conrad AO, Uwaifo GI. Phentermine and topiramate for the management of obesity: a review. Drug Des Devel Ther. 2013; 7: 267-278.

Costello JF, Plass C. Methylation matters. J Med Genet. 2001; 38: 285-303.

Danielzik S, Langnäse K, Mast M, Spethmann C, Müller MJ.Impact of parental BMI on the manifestation of overweight 5-7 year old children. Eur J Nutr. 2002; 41(3): 132-138.

Day FR, Loos RJ. Developments in obesity genetics in the era of genome-wide association studies. J Nutrigenet Nutrigenomics. 2011; 4: 222-238.

Deliard S, Panossian S, Mentch FD, Kim CE, Hou C, Frackelton EC, Bradfield JP, Glessner JT, Zhang $\mathrm{H}$, Wang $\mathrm{K}$, et al. The missense variation landscape of FTO, MC4R, and TMEM18 in obese children of African Ancestry. Obesity (Silver Spring). 2013; 21(1): 159-163.

Dina C, Meyre D, Gallina S, Durand E, Körner A, Jacobson P, Carlsson LM, Kiess W, Vatin V, Lecoeur C, et al. Variation in FTO contributes to childhood obesity and severe adult obesity. Nat Genet. 2007; 39(6): 724-726.

Dubern B, Clément K. Leptin and leptin receptor-related monogenic obesity. Biochimie. 2012; 94: 2111-2115.

Enattah NS, Sahi T, Savilahti E, Terwilliger JD, Peltonen L, Jãverlã I. Identification of a variant associated with adult-type hypolactasia. Nat Genet. 2002 30: 233-237.

Fang H, Li Y, Du S, Hu X, Zhang Q, Liu A, Ma G. Variant rs9939609 in the FTO gene is associated with body mass index among Chinese children. BMC Med Genet. 2010; 11: e136.

Farooqi IS, Keogh JM, Yeo GS, Lank EJ, Cheetham T, O'Rahilly S. Clinical spectrum of obesity and mutations in the melanocortin 4 receptor gene. N Engl J Med. 2003; 348: 1085-1095. 
Farooqi S, O’Rahilly S. Monogenic obesity in humans. Annu Rev Med. 2005; 56: 443-458.

Fawcett KA, Barroso I.The genetics of obesity: FTO leads the way. Trends Genet. 2010; 26(6): 266-274.

Feinleib M, Garrison RJ, Fabsitz R, Christian JC, Hrubec Z, Borhani NO, Kannel WB, Rosenman R, Schwartz JT, Wagner JO. The NHLBI twin study of cardiovascular disease risk factors: methodology and summary of results. Am J Epidemiol. 1977; 106(4): 284-285.

Finucane MM, Stevens GA, Cowan MJ, Danaei G, Lin JK, Paciorek CJ, Singh GM, Gutierrez HR, Lu Y, Bahalim AN, et al. National, regional, and global trends in body-mass index since 1980: systematic analysis of health examination surveys and epidemiological studies with 960 country-years and 9.1 million participants. Lancet. 2011; 377(9765): 557-567.

Fischer J, Koch L, Emmerling C, Vierkotten J, Peters T, Brüning JC, Rüther U. Inactivation of the Fto gene protects from obesity. Nature. 2009; 458: 894-898.

Frayling TM, Timpson NJ, Weedon MN, Zeggini E, Freathy RM, Lindgren CM, Perry JR, Elliott $\mathrm{KS}$, Lango $\mathrm{H}$, Rayner NW, et al. A common variant in the FTO gene is associated with body mass index and predisposes to childhood and adult obesity. Science. 2007; 316(5826): 889894.

Gantz I, Miwa H, Konda Y, Shimoto Y, Tashiro T, Watson SJ, DelValle J, Yamada T. Molecular cloning, expression, and gene localization of a fourth melanocortin receptor. J Biol Chem. 1993; 268: 15174-15179.

Geller F, Reichwald K, Dempfle A, Illig T, Vollmert C, Herpertz S, Siffert W, Platzer M, Hess C, Gudermann T, et al. Melanocortin-4 receptor gene variant I103 is negatively associated with obesity. Am J Hum Genet. 2004; 74(3): 572-581.

Gemma C, Sookoian S, Alvariñas J, García SI, Quintana L, Kanevsky D, González CD, Pirola CJ. Maternal pregestational BMI is associated with methylation of the PPARGC1A promoter in newborns. Obesity (Silver Spring). 2009; 17: 1032-1039. 
Gerken T, Girard CA, Tung YC, Webby CJ, Saudek V, Hewitson KS, Yeo GS, McDonough MA, Cunliffe S, McNeill LA, et al. The obesity-associated FTO gene encodes a 2-oxoglutaratedependent nucleic acid demethylase. Science. 2007; 318: 1469-1472.

Godfrey KM, Sheppard A, Gluckman PD, Lillycrop KA, Burdge GC, McLean C, Rodford J, Slater-Jefferies JL, Garratt E, Crozier SR, et al. Epigenetic gene promoter methylation at birth is associated with child's later adiposity. Diabetes. 2011; 60: 1528-1534.

González JR, Estévez MN, Giralt PS, Cáceres A, Pérez LM, González-Carpio M, Ballester F, Sunyer J, Rodríguez-López R. Genetic risk profiles for a childhood with severely overweight. Pediatr Obes. 2014; 9: 72-80.

González JR, González-Carpio M, Hernández-Sáez R, Serrano Vargas V, Torres Hidalgo G, Rubio-Rodrigo M, García-Nogales A, Núñez Estévez M, Luengo Pérez LM, Rodríguez-López R. FTO risk haplotype among early onset and severe obesity cases in a population of western Spain. Obesity (Silver Spring). 2012; 20(4): 909-915.

González-Jiménez E, Aguilar Cordero MJ, Padilla López CA, García García I. Monogenic human obesity: role of the leptin-melanocortin system in the regulation of food intake and body weight in humans. An Sist Sanit Navar. 2012; 35(2): 285-293.

Grant SF, Li M, Bradfield JP, Kim CE, Annaiah K, Santa E, Glessner JT, Casalunovo T, Frackelton EC, Otieno FG, et al. Association analysis of the FTO gene with obesity in children of Caucasian and African ancestry reveals a common tagging SNP. PLoS ONE. 2008; 3: e1746.

Han Z, Niu T, Chang J, Lei X, Zhao M, Wang Q, Cheng W, Wang J, Feng Y, Chai J. Crystal structure of the FTO protein reveals basis for its substrate specificity. Nature. 2010; 464: 1205-1209.

Harrold JA, Williams G. Melanocortin-4 receptors, beta-MSH and leptin: key elements in the satiety pathway. Peptides. 2006; 27: 365-371.

Haslam DW, James WP. Obesity. Lancet. 2005; 366: 1197-1209. 
Hassanein MT, Lyon HN, Nguyen TT, Akylbekova EL, Waters K, Lettre G, Tayo B, Forrester T, Sarpong DF, Stram DO, et al. Fine mapping of the association with obesity at the FTO locus in African derived populations. Hum Mol Genet. 2010; 19: 2907-2916.

Heard-Costa NL, Zillikens MC, Monda KL, Johansson A, Harris TB, Fu M, Haritunians T, Feitosa MF, Aspelund T, Eiriksdottir G, et al. NRXN3 is a novel locus for waist circumference: a genome-wide association study from the CHARGE Consortium. PLoS Genet. 2009; 5: e1000539.

Heid IM, Jackson AU, Randall JC, Winkler TW, Qi L, Steinthorsdottir V, Thorleifsson G, Zillikens MC, Speliotes EK, Mägi R, et al. Meta-analysis identifies 13 new loci associated with waist-hip ratio and reveals sexual dimorphism in the genetic basis of fat distribution. Nat Genet. 2010; 42(11): 949-960.

Heijmans BT, Tobi EW, Stein AD, Putter H, Blauw GJ, Susser ES, Slagboom PE, Lumey LH. Persistent epigenetic differences associated with prenatal exposure to famine in humans. Proc Natl Acad Sci. 2008; 105(44): 17046-17049.

Heneghan HM, Miller N, McAnena OJ, O'Brien T, Kerin MJ. Differential miRNA expression in omental adipose tissue and in the circulation of obese patients identifies novel metabolic biomarkers. J Clin Endocrinol Metab. 2011; 96: e846-850.

Hennig BJ, Fulford AJ, Sirugo G, Rayco-Solon P, Hattersley AT, Frayling TM, Prentice AM. FTO gene variation and measures of body mass in an African population. BMC Med Genet. 2009; 10: 21 .

Herbert A, Gerry NP, McQueen MB, Heid IM, Pfeufer A, Illig T, Wichmann HE, Meitinger T, Hunter D, Hu FB, et al. A common genetic variant is associated with adult and childhood obesity. Science. 2006; 312: 279-283.

Herring MP, Sailors MH, Bray MS. Genetic factors in exercise adoption, adherence and obesity. Obes Rev. 2014; 15(1): 29-39. 
Hinney A, Hebebrand J. Polygenic obesity in humans. Obes facts. 2008; 1(1): 35-42.

Hinney A, Vogel Cl, Hebebrand J. From monogenic to polygenic obesity: recent advances. Eur Child Adolesc Psychiatry. 2010; 19(3): 297-310.

Hinney A, Volckmar AL, Knoll N. Melanocortin-4 receptor in energy homeostasis and obesity pathogenesis. Prog Mol Biol Transl Sci. 2013; 114: 147-191.

Horne BD, Anderson JL, Carlquist JF, Muhlestein JB, Renlund DG, Bair TL, Pearson RR, Camp NJ. Generating genetic risk scores from intermediate phenotypes for use in association studies of clinically significant endpoints. Ann Hum Genet. 2005; 69(Pt 2): 176-186.

Hotta K, Nakata Y, Matsuo T, Kamohara S, Kotani K, Komatsu R, Itoh N, Mineo I, Wada J, Masuzaki $\mathrm{H}$, et al. Variations in the FTO gene are associated with severe obesity in the Japanese. J Hum Genet. 2008; 53(6): 546-553.

Huszar D, Lynch CA, Fairchild-Huntress V, Dunmore JH, Fang Q, Berkemeier LR, Gu W, Kesterson RA, Boston BA, Cone RD, et al. Targeted disruption of the melanocortin-4 receptor results in obesity in mice. Cell. 1997; 88: 131-141.

Ichihara S, Yamada Y. Genetic factors for human obesity. Cell Mol Life Sci. 2008; 65(7-8): 1086-1098.

Jacobsson J, Schiöth H, Fredriksson R. The impact of intronic single nucleotide polymorphisms and ethnic diversity for studies on the obesity gene FTO. Obes Rev. 2012; 13(12): 1096-1109.

Jia G, Fu Y, Zhao X, Dai Q, Zheng G, Yang Y, Yi C, Lindahl T, Pan T, Yang YG, He C. N6methyladenosine in nuclear RNA is a major substrate of the obesity-associated FTO. Nat Chem Biol. 2011; 7: 885-887.

Kajimoto K, Naraba H, Iwai N. MicroRNA and 3T3-L1 pre-adipocyte differentiation. Rna. 2006; 12: 1626-1632. 
Keller P, Gburcik V, Petrovic N, Gallagher IJ, Nedergaard J, Cannon B, Timmons JA. Gene-chip studies of adipogenesis-regulated microRNAs in mouse primary adipocytes and human obesity. BMC Endocr Disord. 2011; 11: 7.

Kettunen J, Silander K, Saarela O, Amin N, Müller M, Timpson N, Surakka I, Ripatti S, Laitinen $\mathrm{J}$, Hartikainen AL, et al. European lactase persistence genotype shows evidence of association with increase in body mass index. Hum Mol Genet. 2010; 19: 1129-1136.

Kilpeläinen TO, Qi L, Brage S, Sharp SJ, Sonestedt E, Demerath E, Ahmad T, Mora S, Kaakinen $\mathrm{M}$, Sandholt $\mathrm{CH}$, et al. Physical activity attenuates the influence of FTO variants on obesity risk: a meta-analysis of 218,166 adults and 19,268 children. PLoS Med. 2011a; 8(11): e1001116.

Kilpeläinen TO, Zillikens MC, Stančákova A, Finucane FM, Ried JS, Langenberg C, Zhang W, Beckmann JS, Luan J, Vandenput L, et al. Genetic variation near IRS1 associates with reduced adiposity and an impaired metabolic profile. Nat Genet. 2011b; 43: 753-760.

Kim JK, Samaranayake M, Pradhan S. Epigenetic mechanisms in mammals. Cell Mol Life Sci. 2009; 66(4): 596-612.

Kimura M. The neutral theory of molecular evolution. 1983. Cambridge: Cambridge University Press.

Klöting N, Berthold S, Kovacs P, Schön MR, Fasshauer M, Ruschke K, Stumvoll M, Blüher M. MicroRNA expression in human omental and subcutaneous adipose tissue. PLoS One. 2009; 4: e4699.

Knowler WC, Pettitt DJ, Saad MF, Bennett PH. Diabetes mellitus in the Pima Indians: incidence, risk factors and pathogenesis. Diabetes Metab Rev. 1990; 6(1): 1-27.

Kucharski R, Maleszka J, Foret S, Maleszka R. Nutritional Control of Reproductive Status in Honeybees via DNA Methylation. Science. 2008; 319: 1827-1830.

León-Mimila P, Villamil-Ramírez H, Villalobos-Comparán M, Villarreal-Molina T, Romero- 
Hidalgo S, López-Contreras B, Gutiérrez-Vidal R, Vega-Badillo J, Jacobo-Albavera L, PosadasRomeros $\mathrm{C}$, et al. Contribution of common genetic variants to obesity and obesity-related traits in Mexican children and adults. PLoS One. 2013; 8(8): e70640.

Li S, Zhao JH, Luan J, Luben RN, Rodwell SA, Khaw KT, Ong KK, Wareham NJ, Loos RJ. Cumulative effects and predictive value of common obesity-susceptibility variants identified by genome-wide association studies. Am J Clin Nutr. 2010; 91(1): 184-190.

Lindgren CM, Heid IM, Randall JC, Lamina C, Steinthorsdottir V, Qi L, Speliotes EK, Thorleifsson G, Willer CJ, Herrera BM, et al. Genome-wide association scan meta-analysis identifies three Loci influencing adiposity and fat distribution. PLoS Genet. 2009; 5: e1000508.

Llewellyn $\mathrm{CH}$, Trzaskowski M, Plomin R, Wardle J. Finding the missing heritability in pediatric obesity: the contribution of genome-wide complex trait analysis. Int J Obes (Lond). 2013; 37(11): 1506-1509.

Loos RJ, Lindgren CM, Li S, Wheeler E, Zhao JH, Prokopenko I, Inouye M, Freathy RM, Attwood AP, Beckmann JS, et al. Common variants near MC4R are associated with fat mass, weight and risk of obesity. Nat Genet. 2008; 40(6): 768-775.

Loos RJ, Rankinen T, Tremblay A, Perusse L, Chagnon Y, Bouchard C. Melanocortin-4 receptor gene and physical activity in the Quebec Family Study. Int J Obes (Lond). 2005; 29: $420-428$.

Loss RJ. Genetic determinants of common obesity and their value in prediction. Best Pract Res Clin Endocrinol Metab. 2012; 26: 211-226.

Lutz T, Woods S. Overview of animal models of obesity. Curr Protoc Pharmacol. 2012; 5: 61.

Mačeková S, Bernasovský I, Gabriková D, Bôžiková A, Bernasovská J, Boroňová I, Behulová R, Svíčková P, Petrejčíková E, Soták M, et al. Association of the FTO rs9939609 polymorphism with obesity in Roma/Gypsy population. Am J Phys Anthropol. 2012; 147(1): 30-34. 
Magnusson PK, Rasmussen F. Familial resemblance of body mass index and familial risk of high and low body mass index. A study of young men in Sweden. Int J Obes Relat Metab Disord. 2002; 26: 1225-1231.

Mamun AA, O'Callaghan M, Callaway L, Williams G, Najman J, Lawlor DA. Associations of gestational weight gain with offspring body mass index and blood pressure at 21 years of age: evidence from a birth cohort study. Circulation. 2009; 119: 1720-1727.

Mardis ER. Next-generation sequencing platforms. Annu Rev Anal Chem. 2013; 6: 287-303.

Marian AJ. Molecular genetic studies of complex phenotypes. Transl Res. 2012; 159(2): 6479.

Mathes WF, Aylor DL, Miller DR, Churchill GA, Chesler EJ, de Villena FP, Threadgill DW, Pomp D. Architecture of energy balance traits in emerging lines of the Collaborative Cross. Am J Physiol Endocrinol Metab. 2011; 300(6): e1124-e1134.

McKay J, Mathers J. Diet induced epigenetic changes and their implications for Health. Acta Physiol. 2011; 202: 103-118.

Milagro Fl, Campión J, Garcia-Diaz DF, Goyenechea E, Paternain L, Martinez JÁ. High fat dietinduced obesity modifies the methylation pattern of leptin promoter in rats. J Physiol Biochem. 2009; 65: 1-9.

Milner JA. Molecular targets for bioactive food components. J Nutr. 2004; 134(9): 2492S$2498 S$.

Mitchell JA, Hakonarson H, Rebbeck TR, Grant SF. Obesity-Susceptibility Loci and the Tails of the Pediatric BMI Distribution. Obesity. 2013; 21: 1256-1260.

Monda KL, Chen GK, Taylor KC, Palmer C, Edwards TL, Lange LA, Ng MC, Adeyemo AA, Allison MA, Bielak LF, et al. A meta-analysis identifies new loci associated with body mass index in individuals of African ancestry. Nat Genet. 2013; 45(6): 690-696. 
Montague CT, Farooqi IS, Whitehead JP, Soos MA, Rau H, Wareham NJ, Sewter CP, Digby JE, Mohammed SN, Hurst JA, et al. Congenital leptin deficiency is associated with severe earlyonset obesity in humans. Nature. 1997; 387: 903-908.

Moore LL, Lombardi DA, White MJ, Campbell JL, Oliveria SA, Ellison RC. Influence of parents' physical activity levels on activity levels of young children. J Pediatr. 1991; 118: 215-219.

Mountjoy KG, Mortrud MT, Low MJ, Simerly RB, Cone RD. Localization of the melanocortin-4 receptor (MC4-R) in neuroendocrine and autonomic control circuits in the brain. Mol Endocrinol. 1994; 8: 1298-1308.

Mutch DM, Clément K. Unravelling the genetics of human obesity. PLoS Genet. 2006; 2: e188.

Myles S, Lea RA, Ohashi J, Chambers GK, Weiss JG, Hardouin E, Engelken J, MacartneyCoxson DP, Eccles DA, Naka I, et al. Testing the thrifty gene hypothesis: the Gly482Ser variant in PPARGC1A is associated with BMI in Tongans. BMC Med Genet. 2011; 12: 10.

Nakayama K, Ogawa A, Miyashita H, Tabara Y, Igase M, Kohara K, Miki T, Kagawa Y, Yanagisawa $Y$, Katashima M, et al. Positive natural selection of TRIB2, a novel gene that influences visceral fat accumulation, in East Asia. Hum Genet. 2013; 132(2): 201-217.

Neel JV. Diabetes mellitus: a "thrifty" genotype rendered detrimental by "progress"? Bulletin of the WHO. 1962; 77(8): 694-703.

Nielsen R. Molecular signatures of natural selection. Ann Rev Genet. 2005; 39: 197-218.

Ntalla I, Panoutsopoulou K, Vlachou P, Southam L, William Rayner N, Zeggini E, Dedoussis GV. Replication of Established Common Genetic Variants for Adult BMI and Childhood Obesity in Greek Adolescents: The TEENAGE Study. Ann Hum Genet. 2013; 77(3): 268-274.

O'Connor A, Swick A. Interface between Pharmacotherapy and Genes in Human Obesity. Hum Hered. 2013; 75: 116-126. 
Ohashi J, Naka I, Kimura R, Natsuhara K, Yamauchi T, Furusawa T, Nakazawa M, Ataka Y, Patarapotikul J, Nuchnoi P, et al. FTO polymorphisms in oceanic populations. J Hum Genet. 2007; 52: 1031-1035.

O'Rahilly S, Farooqi SI. Human Obesity: A Heritable Neurobehavioral Disorder That Is Highly Sensitive to Environmental Conditions. Diabetes. 2008; 57(11): 2905-2910.

Ortega FJ, Mercader JM, Catalán V, Moreno-Navarrete JM, Pueyo N, Sabater M, GómezAmbrosi J, Anglada R, Fernández-Formoso JA, Ricart W, et al. Targeting the Circulating MicroRNA Signature of Obesity. Clin Chem. 2013; 59(5): 781-792.

Ortega FJ, Moreno-Navarrete JM, Pardo G, Sabater M, Hummel M, Ferrer A, RodriguezHermosa JI, Ruiz B, Ricart W, Peral B, et al. MiRNA expression profile of human subcutaneous adipose and during adipocyte differentiation. PLoS One. 2010; 5: e9022.

Ortega-Azorín C, Sorlí JV, Asensio EM, Coltell O, Martínez-González MÁ, Salas-Salvadó J, Covas MI, Arós F, Lapetra J, Serra-Majem L, et al. Associations of the FTO rs9939609 and the MC4R rs17782313 polymorphisms with type 2 diabetes are modulated by diet, being higher when adherence to the Mediterranean diet pattern is low. Cardiovasc Diabetol. 2012; 11: 137.

Peters T, Ausmeier K, Dildrop R, Rüther U. The mouse fused toes (Ft) mutation is the result of a 1.6-Mb deletion including the entire Iroquois B gene cluster. Mamm Genome. 2002; 13(4): 186-188.

Qi Q, Chu AY, Kang JH, Jensen MK, Curhan GC, Pasquale LR, Ridker PM, Hunter DJ, Willett WC, Rimm EB, et al. Sugar-sweetened beverages and genetic risk of obesity. N Eng J Med. 2012; 367: 1387-1396.

Ramachandrappa S, Farooqi IS. Genetic approaches to understanding human obesity. J Clin Invest. $2011 ; 121(6)$ : 2080-2086.

Ranadive SA, Vaisse C. Lessons from extreme human obesity: monogenic disorders. Endocrinol Metab Clin North Am. 2008; 37(3): 733-751. 
Rankinen T, Zuberi A, Chagnon YC, Weisnagel SJ, Argyropoulos G, Walts B, Pérusse L, Bouchard C. The human obesity gene map: the 2005 update. Obesity (Silver Spring). 2006; 14: 529-644.

Rau H, Reaves BJ, O'Rahilly S, Whitehead JP. Truncated human leptin (delta133) associated with extreme obesity undergoes proteasomal degradation after defective intracellular transport. Endocrinology. 1999; 140: 1718-1723.

Ravussin E, Bouchard C. Human genomics and obesity: finding appropriate drug targets. Eur J Pharmacol. 2000; 410(2-3): 131-145.

Razquin C, Marti A, Martinez JA. Evidences on three relevant obesogenes: MC4R, FTO and PPARY. Approaches for personalized nutrition. Mol Nutr Food Res. 2011; 55: 136-149.

Rey D, Fernandez-Honrado M, Areces C, Algora M, Abd-El-Fatah-Khalil S, Enriquez-deSalamanca M, Coca C, Arribas I, Arnaiz-Villena A. Amerindians show no association of PC-1 gene Gln121 allele and obesity: a thrifty gene population genetics. Mol Biol Rep. 2012; 39(7): 7687-7693.

Richardson AS, North KE, Graff M, Young KM, Mohlke KL, Lange LA, Lange EM, Harris KM, Gordon-Larsen P. Moderate to vigorous physical activity interactions with genetic variants and body mass index in a large US ethnically diverse cohort. Pediatric Obesity. 2014; 9(2): e35-e46.

Rodríguez-López R, González-Carpio M, Serrano MV, Torres G, García de Cáceres MT, Herrera T, Román A, Rubio M, Méndez P, Hernández-Sáez R, et al. Association of FTO gene polymorphisms and morbid obesity in the population of Extremadura. Endocrinol Nutr. 2010; 57(5): 203-209.

Rönn T, Volkov P, Davegårdh C, Dayeh T, Hall E, Olsson AH, Nilsson E, Tornberg A, Dekker Nitert $\mathrm{M}$, Eriksson KF, et al. A six months exercise intervention influences the genome-wide DNA methylation pattern in human adipose tissue. PLoS Genet. 2013; 9(6): e1003572. 
Saeed S, Bonnefond A, Manzoor J, Philippe J, Durand E, Arshad M, Sand O, Butt TA, Falchi M, Arslan M, Froguel P. Novel LEPR mutations in obese Pakistani children identified by PCRbased enrichment and next generation sequencing. Obesity (Silver Spring). 2014; 22(4): 1112-1117.

Sällman Almén M, Rask-Andersen M, Jacobsson JA, Ameur A, Kalnina I, Moschonis G, Juhlin $S$, Bringeland N, Hedberg LA, Ignatovica V, et al. Determination of the obesity-associated gene variants within the entire FTO gene by ultra-deep targeted sequencing in obese and lean children. Int J Obes (Lond). 2013; 37(3): 424-431.

Sandholt $\mathrm{CH}$, Hansen T, Pedersen $\mathrm{O}$. Beyond the fourth wave of genome-wide obesity association studies. Nutr Diabetes. 2012; 2: e37.

Saunders CL, Chiodini BD, Sham P, Lewis CM, Abkevich V, Adeyemo AA, de Andrade M, Arya R, Berenson GS, Blangero J, et al. Meta-analysis of genome-wide linkage studies in BMI and obesity. Obesity. 2007; 15: 2263-2275.

Scuteri A, Sanna S, Chen WM, Uda M, Albai G, Strait J, Najjar S, Nagaraja R, Orrú M, Usala G, et al. Genome-wide association scan shows genetic variants in the FTO gene are associated with obesity-related traits. PLoS Genet. 2007; 3(7): 1200-1210.

Silventoinen K, Rokholm B, Kaprio J, Sørensen TI. The genetic and environmental influences on childhood obesity: a systematic review of twin and adoption studies. Int J Obes. 2010; 34(1): 29-40.

Slatkin M. Linkage disequilibrium-understanding the evolutionary past and mapping the medical future. Nat Rev. 2008; 9(6): 477-485.

Smemo S, Tena JJ, Kim KH. Obesity-associated variants within FTO form long-range functional connections with IRX3. Nature. 2014; 507(7492): 371-375.

Song Y, You NC, Hsu YH, Howard BV, Langer RD, Manson JE, Nathan L, Niu T, F Tinker L, Liu S. FTO Polymorphisms are associated with obesity but not diabetes risk in postmenopausal women. Obesity (Silver Spring). 2008; 16(11): 2472-2480. 
Speakman JR, Rance KA, Johnstone AM. Polymorphisms of the FTO gene are associated with variation in energy intake, but not energy expenditure. Obesity (Silver Spring). 2008; 16: 1961-1965.

Speakman JR. Evolutionary Perspectives on the Obesity Epidemic: Adaptive, Maladaptive, and Neutral Viewpoints. Annu Rev Nutr. 2013; 33: 289-317.

Speakman JR. Obesity: the integrated roles of environment and genetics. J Nutrition. 2004; 134: 2090S-2105S.

Speakman JR. Thrifty genes for obesity and the metabolic syndrome-time to call off the search? Diab Vasc Dis Res. 2006; 3(1): 7-11.

Speakman JR. Thrifty genes for obesity, an attractive but flawed idea, and an alternative perspective: the 'drifty gene' hypothesis. Int J Obes (Lond). 2008; 32(11): 1611-1617.

Speliotes EK, Willer CJ, Berndt SI, Monda KL, Thorleifsson G, Jackson AU, Lango Allen H, Lindgren CM, Luan J, Mägi R, et al. Association analyses of 249,796 individuals reveal 18 new loci associated with body mass index. Nat Genet. 2010; 42(11): 937-948.

Steemburgo T, Azevedo MJ, Gross JL, Milagro Fl, Campión J, Martínez JÁ. The rs9939609 polymorphism in the FTO gene is associated with fat and fiber intakes in patients with type 2 diabetes. J Nutrigenet Nutrigenomics. 2013; 6(2): 97-106.

Steemburgo T, Azevedo MJ, Martínez JÁ. Gene-nutrient interaction and its association with obesity and diabetes mellitus. Arq Bras Endocrinol Metabol. 2009; 53(5): 497-508.

Stefan N, Vozarova B, Del Parigi A, Ossowski V, Thompson DB, Hanson RL, Ravussin E, Tataranni PA. The Gln223Arg polymorphism of the leptin receptor in Pima Indians: influence on energy expenditure, physical activity and lipid metabolism. Int J Obes Relat Metab Disord. 2002; 26: 1629-1632.

Strobel A, Issad T, Camoin L, Ozata M, Strosberg AD. A leptin missense mutation associated 
with hypogonadism and morbid obesity. Nat Genet. 1998; 18: 213-215.

Stunkard AJ, Foch TT, Hrubec Z. A twin study of human obesity. JAMA. 1986a; 256(1): 51-54.

Stunkard AJ, Sorensen TI, Hanis C, Teasdale TW, Chakraborty R, Schull WJ, Schulsinger F. An adoption study of human obesity. N Engl J Med. 1986b; 314(4): 193-198.

Swinburn BA, Sacks G, Hall KD, McPherson K, Finegood DT, Moodie ML, Gortmaker SL. The global obesity pandemic: shaped by global drivers and local environments. Lancet. 2011; 378(9793): 804-814.

Takanabe R, Ono K, Abe Y, Takaya T, Horie T, Wada H, Kita T, Satoh N, Shimatsu A, Hasegawa K. Up-regulated expression of microRNA-143 in association with obesity in adipose tissue of mice fed high-fat diet. Biochem Biophys Res Commun. 2008; 376: 728-732.

Tan LJ, Zhu H, He H, Wu KH, Li J, Chen XD, Zhang JG, Shen H, Tian Q, Krousel-Wood M, et al. Replication of 6 obesity genes in a meta-analysis of genome-wide association studies from diverse ancestries. PLoS One. 2014; 9(5): e96149.

Thorleifsson G, Walters GB, Gudbjartsson DF, Steinthorsdottir V, Sulem P, Helgadottir A, Styrkarsdottir U, Gretarsdottir S, Thorlacius S, Jonsdottir I, et al. Genome-wide association yields new sequence variants at seven loci that associate with measures of obesity. Nat Genet. 2009; 42(11): 937-948.

Tung YC, Yeo GS. From GWAS to biology: lessons from FTO. Ann N Y Acad Sci. 2011; 1220: 162-171.

Vaisse C, Clément K, Guy-Grand B, Froguel P. A frameshift mutation in human MC4R is associated with a dominant form of obesity. Nat Genet. 1998; 20: 113-114.

van den Born E, Omelchenko MV, Bekkelund A, Leihne V, Koonin EV, Dolja VV, Falnes $P \emptyset$. Viral AlkB proteins repair RNA damage by oxidative demethylation. Nucl Acids Res. 2008; 36 : 5451-5461. 
Wang X, Zhu H, Snieder H, Su S, Munn D, Harshfield G, Maria BL, Dong Y, Treiber F, Gutin B, Shi $\mathrm{H}$. Obesity related methylation changes in DNA of peripheral blood leukocytes. BMC Medicine. 2010; 8: 87.

Wen W, Cho YS, Zheng W, Dorajoo R, Kato N, Qi L, Chen CH, Delahanty RJ, Okada Y, Tabara $\mathrm{Y}$, et al. Meta-analysis identifies common variants associated with body mass index in East Asians. Nat Genet. 2012; 44(3): 307-311.

Whitaker RC, Wright JA, Pepe MS, Seidel KD, Dietz WH. Predicting obesity in young adulthood from childhood and parental obesity. N Engl J Med. 1997; 337(13): 869-873.

Widiker S, Karst S, Wagener A, Brockmann GA. High-fat diet leads to a decreased methylation of the Mc4r gene in the obese BFMI and the lean B6 mouse lines. J Appl Genet. 2010; 51: 193-197.

Willer CJ, Speliotes EK, Loos RJ, Li S, Lindgren CM, Heid IM, Berndt SI, Elliott AL, Jackson AU, Lamina $C$, et al. Six new loci associated with body mass index highlight a neuronal influence on body weight regulation. Nat Genet. 2009; 41: 25-34.

Williams MD, Mitchell GM. MicroRNAs in insulin resistance and obesity. Exp Diabetes Res. 2012; 2012: 484696.

Xi B, Chandak GR, Shen Y, Wang Q, Zhou D. Association between common polymorphism near the MC4R gene and obesity risk: a systematic review and meta-analysis. PLoS One. 2012; 7(9): e45731.

Xia Q, Grant SF. The genetics of human obesity. Ann N Y Acad Sci. 2013; 1281: 178-190.

Xie $\mathrm{H}$, Lim B, Lodish HF. MicroRNAs induced during adipogenesis that accelerate fat cell development are downregulated in obesity. Diabetes. 2009; 58: 1050-1057.

Xu X, Su S, Barnes VA, De Miguel C, Pollock J, Ownby D, Shi H, Zhu H, Snieder H, Wang X. A genome-wide methylation study on obesity: differential variability and differential 
methylation. Epigenetics. 2013; 8(5): 522-533.

Yang J, Manolio TA, Pasquale LR, Boerwinkle E, Caporaso N, Cunningham JM, de Andrade M, Feenstra B, Feingold E, Hayes MG, et al. Genome partitioning of genetic variation for complex traits using common SNPs. Nat Genet. 2011; 43(6): 519-525.

Yeo GS, Farooqi IS, Aminian S, Halsall DJ, Stanhope RG, O'Rahilly S. A frameshift mutation in MC4R associated with dominantly inherited human obesity. Nat Genet. 1998; 20: 111-112.

Zavattari P, Loche A, Pilia S, Ibba A, Moi L, Guzzetti C, Casini MR, Loche S. rs9939609 in the FTO gene is associated with obesity but not with several biochemical parameters in Sardinian obese children. Ann Hum Genet. 2011; 75: 648-654.

Zhao J, Bradfield JP, Li M, Wang K, Zhang H, Kim CE, Annaiah K, Glessner JT, Thomas K, Garris $M$, et al. The role of obesity-associated loci identified in genome-wide association studies in the determination of pediatric BMI. Obesity (Silver Spring). 2009; 17(12): 2254-2257.

Zhao J, Bradfield JP, Zhang H, Sleiman PM, Kim CE, Glessner JT, Deliard S, Thomas KA, Frackelton EC, Li M, et al. Role of BMI-associated loci identified in GWAS meta-analyses in the context of common childhood obesity in European Americans. Obesity (Silver Spring). 2011; 19: 2436-2439.

Zhao J, Goldberg J, Vaccarino V. Promoter methylation of serotonin transporter gene is associated with obesity measures: a monozygotic twin study. Int J Obes. 2013; 37(1): 140145.

Zhao J, Grant SF. Genetics of Childhood Obesity. J Obes. 2011; 2011: e845148.

Zhu J, Loos RJ, Lu L, Zong G, Gan W, Ye X, Sun L, Li H, Lin X. Associations of genetic risk score with obesity and related traits and the modifying effect of physical activity in a chinese han population. PLoS One. 2014; 9(3): e91442.

Table 1. Monogenic forms (syndromic and non-syndromic) of obesity. 


\section{Non-syndromic forms}

\begin{tabular}{|c|c|c|c|c|}
\hline Gene name & $\begin{array}{c}\text { Gene } \\
\text { symbol }\end{array}$ & $\begin{array}{l}\text { Chromoso- } \\
\text { me location }\end{array}$ & Mutations & Obesity Phenotype \\
\hline Leptin & $L E P$ & $7 q 32.1$ & $\Delta \mathrm{G} 133, \operatorname{Arg} 105 \mathrm{Trp}$ & $\begin{array}{l}\text { Extreme, early-onset obesi- } \\
\text { ty, hyperphagia. }\end{array}$ \\
\hline Leptin receptor & $L E P R$ & $1 \mathrm{p} 31.3$ & $\begin{array}{l}\text { Exon } 16 \text { splice donor } \\
\text { G } \rightarrow \text { A } \\
\text { G7013T, 7133 delC, }\end{array}$ & $\begin{array}{l}\text { Extreme, early-onset obesi- } \\
\text { ty, hyperphagia. }\end{array}$ \\
\hline Pro-opiomelanocortin & POMC & $2 p 23.3$ & $\begin{array}{l}\text { C3804A, A6851T, } \\
\text { 6906delC, 6996del, } \\
\text { 7100insGG, 7134delG }\end{array}$ & Early onset obesity. \\
\hline Proconvertase 1 & PCSK1 & $5 q 15$ & $\begin{array}{l}\text { Gly483Arg, } A \rightarrow C+4 \\
\text { intron } 5 \text { donor splice } \\
\text { site, } \\
\text { Glu250Stop, } \\
\text { Del213Ala }\end{array}$ & $\begin{array}{l}\text { Childhood onset obesity, } \\
\text { elevated proinsulin, } \\
\text { hypocortisolemia, } \\
\text { depressed POMC, } \\
\text { reactive hypoglycemia. }\end{array}$ \\
\hline Melanocortin-4 receptor & $M C 4 R$ & $18 q 21.32$ & $>150$ & $\begin{array}{l}\text { Early onset obesity, } \\
\text { hyperphagia, increased } \\
\text { fat mass, increased lean } \\
\text { mass. }\end{array}$ \\
\hline $\begin{array}{l}\text { Brain-derived neurotrophic } \\
\text { factor }\end{array}$ & $B D N F$ & $11 \mathrm{p} 13$ & $\begin{array}{l}46, X X \\
\operatorname{inv}(11)(p 13 p 15.3)\end{array}$ & $\begin{array}{l}\text { Severe obesity, Hyperphagia, } \\
\text { body weight. }\end{array}$ \\
\hline $\begin{array}{l}\text { Neurotrophic tyrosine } \\
\text { kynase receptor type } 2\end{array}$ & NTRK2 & $9 q 22.1$ & Y722C & $\begin{array}{l}\text { Severe early onset obesity, } \\
\text { hyperphagia. }\end{array}$ \\
\hline Single-minded homolog 1 & SIM1 & $6 q 16.3$ & $\begin{array}{l}\text { de novo balanced } \\
\text { translocation } 1 \mathrm{p} 22.1 \\
\text { and } 6 \mathrm{q} 16.2 \text {. }\end{array}$ & $\begin{array}{l}\text { Early-onset obesity, hypoto- } \\
\text { nia, developmental delay. }\end{array}$ \\
\hline
\end{tabular}

\section{Syndromic forms}

\begin{tabular}{llcl}
\hline \multicolumn{1}{c}{ Syndrome } & Gene & $\begin{array}{c}\text { Chromosome loca- } \\
\text { tion }\end{array}$ & \multicolumn{1}{c}{ Obesity Phenotype } \\
\hline $\begin{array}{l}\text { Prader Willi syndrome } \\
\text { (PWS) }\end{array}$ & $\begin{array}{l}\text { Contiguous } \\
\text { gene disorder }\end{array}$ & $15 \mathrm{q} 11-13$ & $\begin{array}{l}\text { Neonatal hypotonia, poor feeding, } \\
\text { evolving into extreme hyperphagia, } \\
\text { central obesity. }\end{array}$ \\
$\begin{array}{l}\text { Bardet-Biedl syndrome } \\
\text { (BBS) }\end{array}$ & BBS1-BBS12 & $11 \mathrm{q} 13.2$ & progressive late childhood obesity \\
Alstrom syndrome & ALMS1 & $2 \mathrm{p} 13.1$ & Mild truncal obesity \\
WAGR syndrome & BDNF & $11 \mathrm{p} 14.1$ & Obesity \\
$16 \mathrm{p} 11.2$ deletion & & $16 \mathrm{p} 11.2$ & Progressive obesity \\
\hline
\end{tabular}


Table 2. Currently established loci associated with BMI in GWAS.

\begin{tabular}{|c|c|c|c|c|c|}
\hline Wave & Gene symbol & Gene name & SNP ID & $\begin{array}{l}\text { Effect size BMI } \\
(\text { OR } 95 \% \mathrm{Cl})^{*}\end{array}$ & Discovery study \\
\hline First & FTO & Fat mass and obesity associated & rs9939609 & $1.31(1.23-1.39)$ & $\begin{array}{l}\text { Frayling et al. } 2007 \\
\text { Scuteri et al. } 2007\end{array}$ \\
\hline Second & Near MC4R & Melanocortin-4 receptor & rs17782313 & $1.12(1.08-1.16)$ & Loos et al. 2008 \\
\hline \multirow[t]{12}{*}{ Third } & Near TMEM18 & Transmembrane protein 18 & rs7561317 & $1.20(1.13-1.27)$ & \\
\hline & & & rs6548238 & $1.19(1.10-1.26)$ & \\
\hline & FAIM2 & Fas apoptotic inhibitory molecule 2 & rs7138803 & $1.14(1.09-1.19)$ & \\
\hline & Near GNPDA2 & Glucosamine-6-phosphate deaminase 2 & rs10938397 & $1.12(1.07-1.17)$ & \\
\hline & SEC16B & S. cerevisiae Sec16 & rs10913469 & $1.11(1.05-1.18)$ & \\
\hline & $B D N F$ & $\begin{array}{l}\text { Homolog of brain-derived neurotrophic } \\
\text { factor }\end{array}$ & rs925946 & $1.11(1.05-1.16)$ & Willer et al. 2009 \\
\hline & Near ETV5 & Ets variant 5 & rs7647305 & $1.11(1.05-1.17)$ & \multirow{6}{*}{ Thorleifsson et al. 2009} \\
\hline & SH2B1 & SH2B adaptor protein 1 & rs74986665 & $1.11(1.06-1.17)$ & \\
\hline & Near NEGR1 & Neuronal growth regulator 1 & rs2568958 & $1.07(1.02-1.12)$ & \\
\hline & Near KCTD15 & $\begin{array}{l}\text { Potassium channel tetramerization do- } \\
\text { main containing } 15\end{array}$ & rs29941 & $1.10(1.04-1.15)$ & \\
\hline & & & rs11084753 & $1.04(0.98-1.10)$ & \\
\hline & $\mathrm{MTCH} 2$ & Mitochondrial carrier 2 & rs10838738 & $1.03(0.98-1.08)$ & \\
\hline \multirow[t]{3}{*}{ Fourth } & Near PRKD1 & Protein kinase D1 & rs11847697 & $1.10(1.03-1.17)$ & \\
\hline & SLC39A8 & Solute carrier family 39, member 8 & rs13107325 & $1.10(1.05-1.15)$ & \\
\hline & TFAP2B & Transcription factor AP-2 beta & rs987237 & $1.09(1.05-1.12)$ & \\
\hline
\end{tabular}




\begin{tabular}{|c|c|c|c|c|c|}
\hline & $Q P C T L$ & $\begin{array}{l}\text { Glutaminyl-peptide cyclotransferase- } \\
\text { like }\end{array}$ & rs2287019 & $1.09(1.05-1.12)$ & \multirow{17}{*}{ Speliotes et al. 2010} \\
\hline & NRXN3 & neurexin 3 & rs10150332 & $1.09(1.05-1.12)$ & \\
\hline & Near GPRC5B & $\begin{array}{l}\text { G protein-coupled receptor, family C, } \\
\text { group } 5 \text {, member B }\end{array}$ & rs12444979 & $1.08(1.04-1.11)$ & \\
\hline & $\begin{array}{l}\text { Near RBJ- } \\
\text { DNAJC27 }\end{array}$ & $\begin{array}{l}\text { DnaJ (Hsp } 40 \text { ) homolog, subfamily C, } \\
\text { member } 27\end{array}$ & rs713586 & $1.07(1.05-1.09)$ & \\
\hline & MAP2K5 & Mitogen-activated protein kinase 5 & rs2241423 & $1.07(1.04-1.10)$ & \\
\hline & Near TMEM160 & Transmembrane protein 160 & rs3810291 & $1.06(1.03-1.08)$ & \\
\hline & Near FANCL & $\begin{array}{l}\text { fanconi anemia, complementation } \\
\text { group L }\end{array}$ & rs887912 & $1.06(1.03-1.08)$ & \\
\hline & $\begin{array}{l}\text { Near FLJ35779- } \\
\text { POC5 }\end{array}$ & centriolar protein & rs2112347 & $1.05(1.03-1.08)$ & \\
\hline & NearLRP1B & $\begin{array}{l}\text { low density lipoprotein receptor-related } \\
\text { protein 1B }\end{array}$ & rs2890652 & $1.05(1.02-1.08)$ & \\
\hline & MTIF3 & $\begin{array}{l}\text { mitochondrial translational initiation } \\
\text { factor } 3\end{array}$ & rs4771122 & $1.05(1.01-1.08)$ & \\
\hline & LRRN6C & leucine rich repeat neuronal $6 \mathrm{C}$ & rs10968576 & $1.04(1.02-1.06)$ & \\
\hline & TNNI3K & interacting kinase & rs1514175 & $1.04(1.02-1.07)$ & \\
\hline & CADM2 & cell adhesion molecule 2 & rs13078807 & $1.03(1.00-1.06)$ & \\
\hline & NUDT3 & $\begin{array}{l}\text { nucleoside diphosphate linked moiety } X \\
\text { type motif } 3\end{array}$ & rs206936 & $1.03(1.01-1.06)$ & \\
\hline & Near RPL27A & ribosomal protein L27a & rs4929949 & $1.03(1.01-1.05)$ & \\
\hline & Near ZNF608 & izinc finger protein 608 & rs4836133 & $1.03(1.01-1.05)$ & \\
\hline & Near PTBP2 & polypyrimidine tract binding protein 2 & rs1555543 & $1.02(0.99-1.04)$ & \\
\hline \multirow[t]{3}{*}{ Fifth } & GNAT2 & $\begin{array}{l}\text { guanine nucleotide binding protein (G } \\
\text { protein) alpha transducing activity }\end{array}$ & rs17024258 & $1.27(p=0.02)$ & \multirow{3}{*}{ Berndt et al. 2013 } \\
\hline & HS6ST3 & heparin sulphate 6 -0-sulfotransferase 3 & rs79893336 & $1.09(p=0.0001)$ & \\
\hline & HNF4G & hepatocyte nuclear factor 4 , gamma & rs4735692 & $1.09(p=1.97 \times 10-5)$ & \\
\hline
\end{tabular}




\begin{tabular}{|c|c|c|c|}
\hline RPTOR & $\begin{array}{l}\text { regulatory associated protein of MTOR, } \\
\text { complex } 1\end{array}$ & rs7503807 & $1.08(p=7.07 \times 10-5)$ \\
\hline MRPS33P4 & $\begin{array}{l}\text { mitochondrial ribosomal protein } \$ 33 \\
\text { pseudogene } 4\end{array}$ & rs13041126 & $1.08(p=0.001)$ \\
\hline ZZZ3 & zinc finger, ZZ-type containing 3 & rs17381664 & $1.08(p=0.001)$ \\
\hline$A D C Y 9$ & adenylate cyclise 9 & rs2531995 & $1.06(p=0.01)$ \\
\hline
\end{tabular}

Abbreviations: BMI, body mass index; OR, odd ratio; 95\%CI, confidence interval; SNP ID, polymorphism identification.

*Effect size from first discovery study.

\# This study this not reported confidence intervals, but rather P-values. 
Table 3. Few studies with examples of human genes related to obesity through epigenetic mechanisms.

\begin{tabular}{|c|c|c|c|c|c|c|}
\hline $\begin{array}{c}\text { Gene } \\
\text { symbol/EW } \\
\text { AS }\end{array}$ & $\begin{array}{c}\text { Associate } \\
\text { d } \\
\text { genes }\end{array}$ & $\begin{array}{c}\text { Epigeneti } \\
\text { c } \\
\text { mechanis } \\
\text { ms }\end{array}$ & Tissue & $\begin{array}{c}\text { Study } \\
\text { sample }\end{array}$ & $\begin{array}{l}\text { Role in } \\
\text { obesity }\end{array}$ & $\begin{array}{c}\text { Referen } \\
\text { ces }\end{array}$ \\
\hline EWAS & $\begin{array}{l}\text { UBASH3 } \\
A, T R I M 3\end{array}$ & $\begin{array}{l}\text { DNA } \\
\text { methylati } \\
\text { on }\end{array}$ & $\begin{array}{l}\text { Peripheral } \\
\text { blood } \\
\text { leukocytes }\end{array}$ & $\begin{array}{l}14 \\
\text { African- } \\
\text { American } \\
\text { men (14- } \\
18) \\
\text { Replicatio } \\
\text { n: } 46 \\
\text { Obese (14- } \\
18) \text { and 46 } \\
\text { lean (14- } \\
30) \\
\text { African- } \\
\text { American } \\
\text { men }\end{array}$ & Obesity & $\begin{array}{l}\text { Wang et } \\
\text { al. } 2010\end{array}$ \\
\hline $\begin{array}{l}\text { EWAS in } \\
\text { individuals } \\
\text { carriers } \\
\text { FTO risk } \\
\text { allele } \\
\text { (rs9939609) }\end{array}$ & $\begin{array}{l}\text { KARS, } \\
\text { TERF } 2 I P, \\
D E X I, \\
\text { MSI1, } \\
\text { STON1, } \\
\text { BCAS3 }\end{array}$ & $\begin{array}{l}\text { DNA } \\
\text { methylati } \\
\text { on }\end{array}$ & $\begin{array}{l}\text { Whole } \\
\text { blood }\end{array}$ & $\begin{array}{l}33 \text { obese } \\
\text { and } 24 \\
\text { normal- } \\
\text { weight } \\
\text { preadolesc } \\
\text { ent girls } \\
\text { Caucasian } \\
\text { (Greek) } \\
\text { (9-13 } \\
\text { years) }\end{array}$ & Obesity & $\begin{array}{l}\text { Almén et } \\
\text { al. } 2012\end{array}$ \\
\hline SLC6A4 & SLC6A4 & $\begin{array}{l}\text { DNA } \\
\text { methylati } \\
\text { on }\end{array}$ & $\begin{array}{l}\text { Peripheral } \\
\text { blood } \\
\text { leukocytes }\end{array}$ & $\begin{array}{l}84 \mathrm{MZ} \\
\text { twin pairs } \\
\text { Caucasian } \\
(\sim 55.1 \\
\text { year })\end{array}$ & $\begin{array}{l}\text { BMI, body } \\
\text { weight, } \\
\text { waist } \\
\text { circumfere } \\
\text { nce }\end{array}$ & $\begin{array}{l}\text { Zhao et } \\
\text { al. } 2013\end{array}$ \\
\hline $\begin{array}{l}\text { PPARGC1A } \\
\text { PPARG, } \\
\text { Tfam }\end{array}$ & $\begin{array}{l}P P A R G C \\
1 A\end{array}$ & $\begin{array}{l}\text { DNA } \\
\text { methylati } \\
\text { on }\end{array}$ & $\begin{array}{l}\text { Umbilical } \\
\text { cord tissue } \\
\text { and white } \\
\text { blood cells }\end{array}$ & $\begin{array}{l}88 \text { healthy } \\
\text { pregnant } \\
\text { women } \\
(\sim 29.7 \\
\text { year }) \text { and } \\
\text { their } \\
\text { babies }\end{array}$ & $\begin{array}{l}\text { Maternal } \\
\text { BMI }\end{array}$ & $\begin{array}{l}\text { Gemma } \\
\text { et al. } \\
2009\end{array}$ \\
\hline$M C 4 R$ & $M C 4 R$ & $\begin{array}{l}\text { DNA } \\
\text { methylati }\end{array}$ & $\begin{array}{l}\text { Brain } \\
\text { tissues }\end{array}$ & $\begin{array}{l}\text { Berlin fat } \\
\text { mouse }\end{array}$ & Fat diet & $\begin{array}{l}\text { Widiker } \\
\text { et al. }\end{array}$ \\
\hline
\end{tabular}


on

\begin{tabular}{|c|c|c|c|c|c|c|}
\hline EWAS & 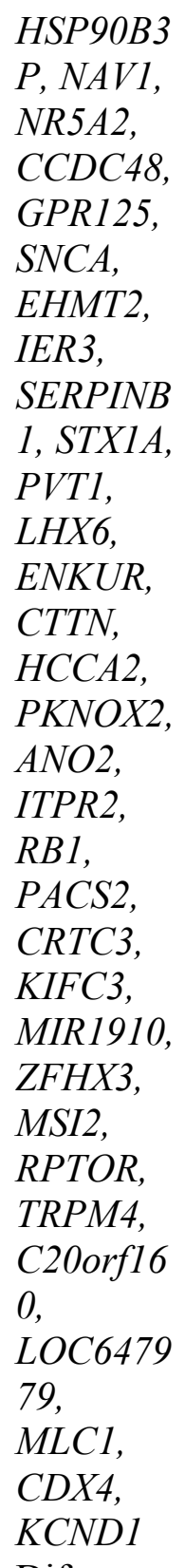 & $\begin{array}{l}\text { DNA } \\
\text { methylati } \\
\text { on, } \\
\text { mRNA } \\
\text { expressio } \\
\text { n }\end{array}$ & $\begin{array}{l}\text { Adipose } \\
\text { tissue }\end{array}$ & $\begin{array}{l}31 \text { healthy } \\
\text { Caucasian } \\
\text { men } \\
\text { (Sweden) } \\
(\sim 37.4)\end{array}$ & $\begin{array}{l}\text { Adipocyte } \\
\text { metabolism }\end{array}$ & $\begin{array}{l}\text { Rönn et } \\
\text { al. } 2013\end{array}$ \\
\hline EWAS & $\begin{array}{l}\text { Diference } \\
\mathrm{s} \text { between } \\
\text { number of } \\
\text { differentia } \\
\text { lly } \\
\text { methylate } \\
\text { d CpG } \\
\text { sites and } \\
\text { number of }\end{array}$ & $\begin{array}{l}\text { DNA } \\
\text { methylati } \\
\text { on }\end{array}$ & $\begin{array}{l}\text { Peripheral } \\
\text { blood } \\
\text { leukocytes }\end{array}$ & $\begin{array}{l}48 \text { obese } \\
\text { and } 48 \\
\text { lean } \\
\text { African- } \\
\text { American } \\
(14-20)\end{array}$ & Obesity & $\begin{array}{l}\text { Xu et al. } \\
2013\end{array}$ \\
\hline
\end{tabular}

(Mus

2010

musculus)

31 healthy Adipocyte Rönn et

men

(Sweden)

GPR125, expressio

EHMT2,

IER3,

SERPINB

1, STX1A,

PVT1,

ENKUR,

CTTN,

HCCA2,

$P K N O X 2$,

AN

ITPR2,

$R B 1$,

PACS2,

CRTC3,

KIFC3,

MIR1910,

ZFHX3,

$M S I 2$,

RPTOR,

TRPM4,

C20orf16

LOC6479

79 ,

$M L C 1$,

$C D X 4$,

KCND1

number of 


\begin{tabular}{|c|c|c|c|c|c|c|}
\hline & $\begin{array}{l}\text { differentia } \\
\text { lly } \\
\text { variable } \\
\text { CpG sites }\end{array}$ & & & & & \\
\hline$L E P$ & $L E P$ & $\begin{array}{l}\text { DNA } \\
\text { methylati } \\
\text { on }\end{array}$ & $\begin{array}{l}\text { Troncal } \\
\text { blood and } \\
\text { retroperiton } \\
\text { eal adipose } \\
\text { tissue }\end{array}$ & $\begin{array}{l}\text { Male } \\
\text { Wistar rats }\end{array}$ & diet & $\begin{array}{l}\text { Milagro } \\
\text { et al. } \\
2009\end{array}$ \\
\hline $\begin{array}{l}\text { RXRA, } \\
\text { eNOS, } \\
\text { SOD } 1, I L 8, \\
P I 3 K C D\end{array}$ & $\begin{array}{l}R X R A \\
e N O S\end{array}$ & $\begin{array}{l}\text { DNA } \\
\text { methylati } \\
\text { on }\end{array}$ & $\begin{array}{l}\text { Umbilical } \\
\text { cord tissue }\end{array}$ & $\begin{array}{l}78 \\
\text { Caucasian } \\
\text { women } \\
(\geq 16) \\
\text { Replicatio } \\
\text { n: } 239 \\
\text { children }\end{array}$ & $\begin{array}{l}\text { Fat mass } \\
\text { and \%fat } \\
\text { mass }\end{array}$ & $\begin{array}{l}\text { Godfrey } \\
\text { et al. } \\
2011\end{array}$ \\
\hline
\end{tabular}




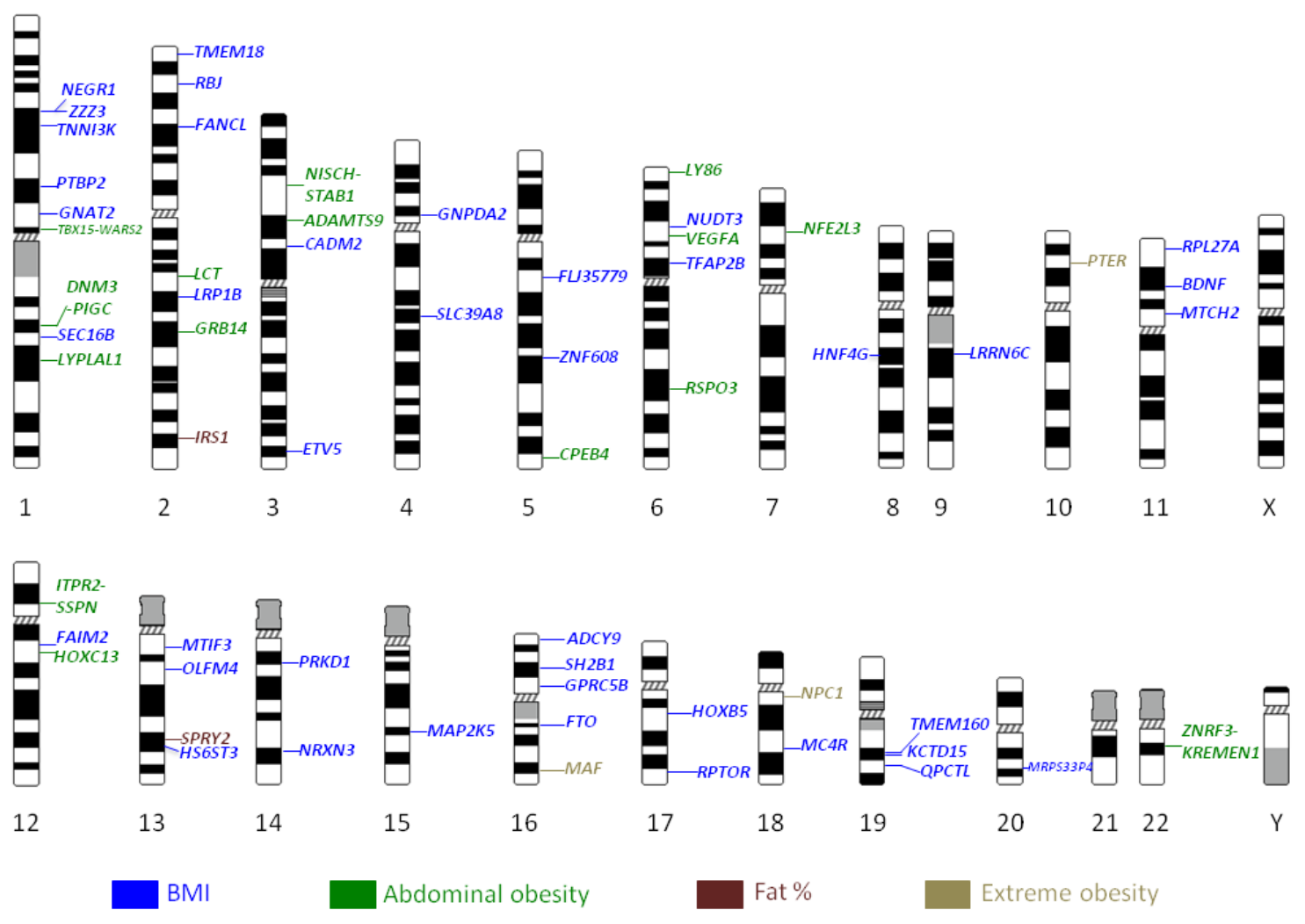

Figure 1. Loci associated with obesity-related phenotypes. Almost in every human chromosome it was found a locus linked to predisposition to obesity-phenotype (BMI, abdominal fat, fat percentage or extreme obesity). 


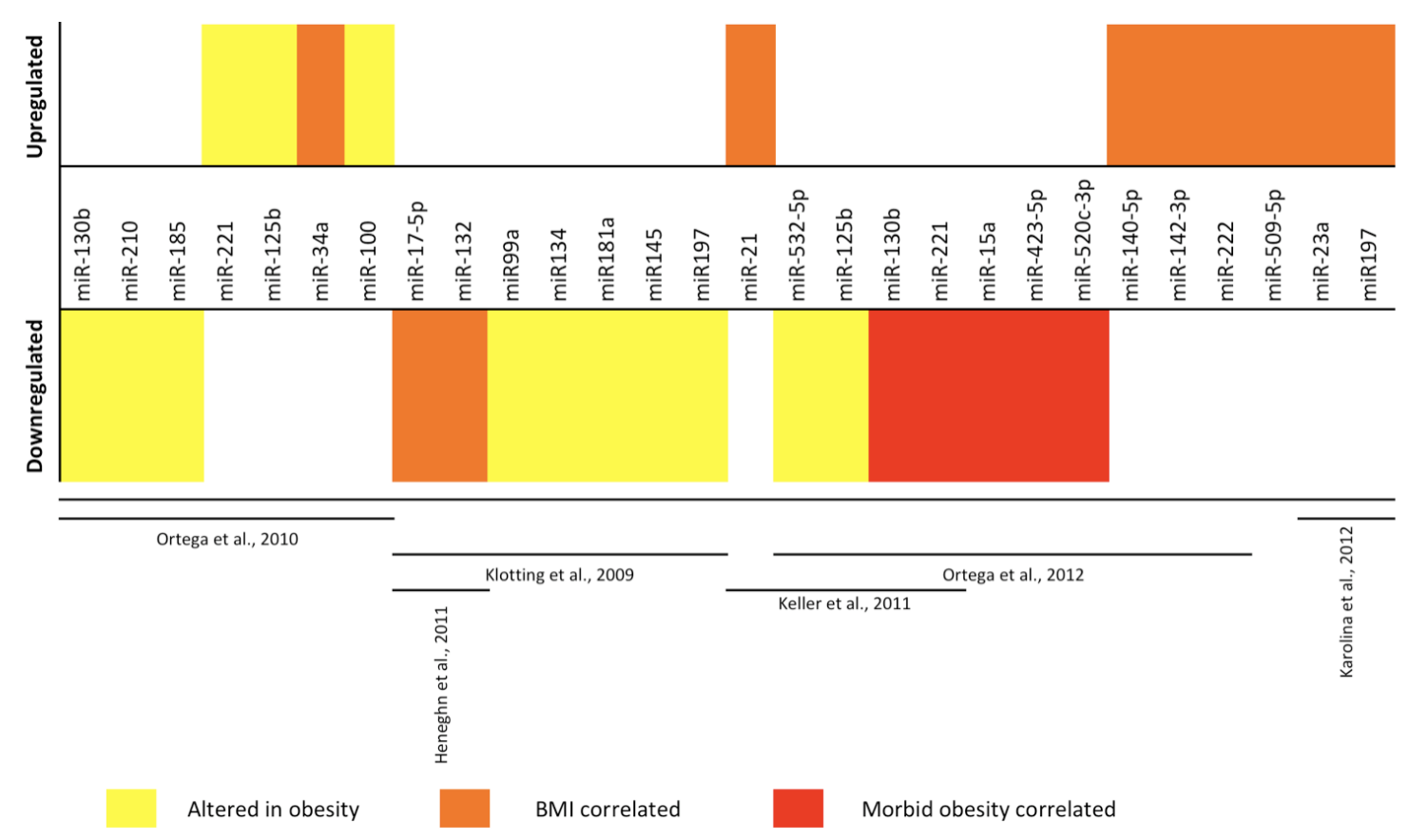

Figure 2. Gene expression profile in obesity-related phenotypes. Several microRNAs were found altered in obesity, and others were found significantly correlated with BMI and morbid obesity. 